\title{
Palaeobotanical research of the Early Miocene deposits overlying the main coal seam (Libkovice and Lom Members) in the Most Basin (Czech Republic)
}

\author{
VASILIS TEODORIDIS \& ZLATKO KVAČEK
}

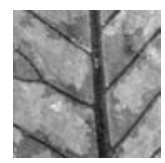

\begin{abstract}
The present article re-evaluates the record of Early Miocene plant megafossils in the upper part of the Most Formation (Libkovice and Lom Members) according to current taxonomy, and applies the results to phytostratigraphical correlation. The characteristics of the floras have been studied, and palaeovegetation has been reconstructed based on leaf, fruit, and seed assemblages for the sites studied within the basin. New methods based on foliar physiognomy (CLAMP) have been used for obtaining palaeoclimatic estimates, and are correlated with additional studies of $\mathrm{CO}_{2}$ concentration. Climatic fluctuations are indicated by changing plant spectra during the deposition of the Libkovice Member. The position of the Miocene climatic optimum has been located in the upper part of the Libkovice Member, and is shown to be of late Early Miocene age. On that basis, this level has been correlated with adjacent regions (e.g., the Cypris Formation of the Cheb Basin, the Upper Coal Seam of the Hrádek part of the Žitava/Zittau Basin). - Key words: palaeoecology, palaeoclimatology, phytostratigraphy, Lower Miocene, leaves, fruits and seeds, Most Basin.
\end{abstract}

TEODORIDIS, V. \& KVAČEK, Z. 2006. Palaeobotanical research of the Early Miocene deposits overlying the main coal seam (Libkovice and Lom Members) in the Most Basin (Czech Republic). Bulletin of Geosciences 81(2), 93-113 (6 figures, 3 tables). Czech Geological Survey, Prague. ISSN 1214-1119. Manuscript received January 12, 2006; accepted in revised form April 10, 2006; issued June 30, 2006.

Vasilis Teodoridis, Charles University, Institute of Biology and Environmental Education, Faculty of Education, M.D. Rettigové 4, 11639 Praha 1, Czech Republic; vasilis.teodoridis@ pedf.cuni.cz•Zlatko Kvaček, Charles University, Institute of Geology and Palaeontology, Albertov 6, 12843 Praha 2, Czech Republic; kvacek@natur.cuni.cz.

An increase of palaeobotanical research in the Most Basin began during the first half of the nineteenth century. However, most published work has been focused on plant fossils from sediments of the main coal seam sensu Elznic et al. (1986) and its clastic equivalents, such as the Holešice Member sensu Domácí (1977) in the areas of the Žatec and the Bílina deltas and other parts of the Most Basin (e.g., Bůžek 1971, Kvaček 1998, Teodoridis 2004). On the other hand, palaeobotanical research of the Libkovice and Lom Members of the Most Formation sensu Domácí (1977), including the floras from the micaceous psammite facies occurring along the Krušné hory Mts. Fault between Vysoká Pec and Albrechtice, has never been completed. Only preliminary information has been available from brief reports (Elznic 1973, Bůžek in Malkovský et al. 1985, pp. 240-241) and systematic studies of individual plant groups (Bůžek \& Holý 1964, Kvaček \& Bůžek 1982, Bůžek et al. 1993, Wójcicki \& Kvaček 2002a, b, Kvaček et al. 2004, Kvaček 2005). Similarly, Hurník (1961, 1973), Kvaček \& Bůžek (1982), and Boulter et al. (1993) identified palaeofloristic areas and distinguished vegetation associations from the Libkovice and Lom Members of the Most Formation.
The present paper gives tentatively complete lists of taxa from the Libkovice and Lom Members based on available fossil carpological and leaf material, in advance of more detailed systematic studies planned for the future. Phytostratigraphical correlations within the Czech Republic and the Boreal European Province, and palaeoenvironmental (including palaeoclimatical) interpretations of the vegetation cover using CLAMP software (see Wolfe 1993), have also been attempted. The results of this work have been correlated with preliminary data from studies of $\mathrm{CO}_{2}$ concentration based on variations in stomatal index and stomatal density (Kuerschner \& Kvaček submitted).

\section{Material and methods}

The fossil carpological material studied here comes from the collections of the late Č. Bůžek and F. Holý from opencast mines, J. Šverma and ČSA, and from the following drill-cores: Břežánky (M 541), Mariánské Radčice (MR 58, MR 59), Libkovice (P 542, Lb 188), Lom (LOM 15), Kundratice (KU 108, KU 114, KU 115, KU 116, KU 127), 


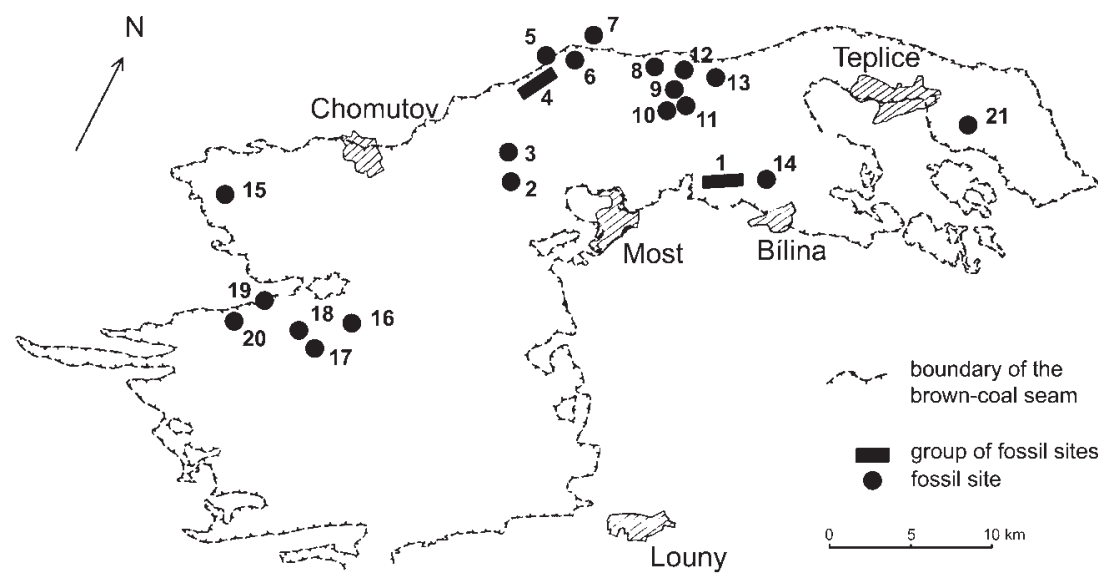

Figure 1. Location of the outcrops and cores studied in the Most Basin. • 1 - Břeštany, Břežánky (Breštany Clay), 2 - opencast mine J. Šverma, 3 - opencast mine ČSA, 4 - Kundratice (KU 108, KU 114, KU 115, KU 116, KU 127), Jezeří (PVJK 234, JZ 42, JZ 44, JZ 47), 5 - Černice, Albrechtice (CN 54, CN 85, Al 55), 6 - Dolní Jiřetín, Horní Jiřetín (HJi 142), 7 - Janov (Ja 28), 8 - Horní Litvínov (LiH 13), 9 - Mariánské Radčice (MR 59), 10 - Mariánské Radčice (MR 58), 11 - Libkovice (Lb 188, P 542), 12 - Lom (LOM 15, LOM 16), 13 - Osek (Os 9), 14 - Břežánky (M 541), 15 - opencast mine Merkur-North, 16 Př́ivlaky, 17 - Soběsuky, 18 - Nechranice, 19 Čermníky, 20 - Dolany, 21 - Nechvalice. and Jezeří (PVJK 234) (for further details see Kvaček \& Bůžek 1982). The fossil leaf material studied here was collected from areas at which the Bílina-Břeštany Clay is exposed at the localities Břeštany, Břežánky, and Jenišův Újezd, including the classic material described by Unger (1847, 1852, 1861, 1864, 1866) and Ettingshausen (1866, 1868, 1869) and at the Žatec Delta (Přívlaky, Čermníky, Dolany, Soběsuky, Nechranice). Other localities include the opencast mines ČSA and J. Šverma, Nechvalice and Dolní Jiřetín, and new collections from the Merkur-North opencast mine at Tušimice. Similarly, the leaf fragments have been collected from cores sampled from various parts of the basin, such as KU 108, KU 115, KU 127, PVJK 234 (Kundratice), JZ 42, JZ 44, JZ 47 (Jezeří), CN 54, CN 85 (Černice), Al 55 (Albrechtice), HJi 142 (Horní Jiřetín), Ja 28 (Janov), LiH 13 (Horní Litvínov), MR 58, MR 59 (Mariánské Radčice), and LOM 16 (Lom) (for further details see Kvaček \& Bůžek 1982). All of the above mentioned localities belong stratigraphically to the Libkovice Member. The material available from the Lom Member was much poorer. The carpological material is known from the cores MR 59 (Mariánské Radčice), LOM 15 (Lom), and the Dolní Jiřetín locality, while leaf remains were taken from the cores MR 59 (Mariánské Radčice), Os 9 (Osek), and LOM 16 (Lom).

Fossil fruits and seeds have been obtained by sieving. The specimens are isolated carbonaceous compressions, often cracked, but still preserved in three dimensions. The fruits of Hemitrapa (Regional Museum, Most) are preserved as impressions. All carpological specimens described here are housed in the National Museum in Prague (NM). Preliminary observations and studies of morphological features were made using a binocular microscope. Scanning electron microscopy (SEM) was used for detailed observations of seed coat structure and for documenting the specimens. The specimens were mounted on brass stubs using nail polish, and remounted with acetone, coated with gold in a sputter coater, and examined using a CAMECA SX 100 scanning electron microscope (Institute of Geology, ASCR, Prague) at $20 \mathrm{kV}$.

The studied leaf fossils are preserved both as impressions and as compressions with cuticles also preserved.

Figure 2. A - Pinus urani (Ung.) Schimper, cone, NM G 8513, core KU 114 (depth 72-73 m), x 1.6. • B - Quasisequoia couttsiae (Heer) Kunzmann, cone, NM G 4093, core P 542 (depth 94-95 m), x 4.•C - Quasisequoia couttsiae (Heer) Kunzmann, seed, NM G 8510, core P 542 (depth 94-95 m), x 6. • D - Taxodium dubium (Sternberg) Heer, cone scale, NM G 8495, opencast mine J. Šverma, x 6. • E - Glyptostrobus europaeus (Brongn.) Ung., cone, NM G 4072, core P 542 (depth 94-95 m), x 4.・F - Glyptostrobus europaeus (Brongn.) Ung., seed, NM G 8511, core P 542 (depth 94-95 m), x 6.5. • G Glyptostrobus europaeus (Brongn.) Ung., seed, NM G 8512, core P 542 (depth 94-95 m), x 6.5. • H - Alnus lusatica Mai, bract, NM G 8496, opencast mine J. Šverma, x 5.5. • I - Alnus lusatica Mai, fruit, NM G 8498, opencast mine J. Šverma, x 9. • J - Pterocarya cf. limburgensis C. \& E.M. Reid, fruit, NM G 8504, core KU 127 (depth 68-69 m), x 9.5.•K - Comptonia goniocarpa Mai, endocarp, NM G 8485, core KU 115 (depth 98.5-98.6 m), x 8.5. • L Comptonia longistyla (Nikitin) Dorofeev, endocarp, NM G 8484, core KU 127 (depth 64-65 m), x 7. • M. Trigonobalanopsis exacantha (Mai) Z. Kvaček \& Walther, fruit, NM G 8499, opencast mine J. Šverma, x 4.5. • N - Myrica ceriferiformis Kownas, fruit with exocarp, NM G 8502 , core KU 115 (depth 99.2-99.3 m), x 10.• O - Myrica suppanii Kirchheimer vel M. ceriferiformis Kownas, endocarp, NM G 8505, core PVJK 234 (depth 62-63 m), x 12 . • PEurya stigmosa (Ludwig) Mai, seed, NM G 8507, core KU 127 (depth 75-76 m), x 20. • Q- Toddalia maii Gregor, seed, NM G 8491 , core KU 127 (depth 68-69 m), x 11. • R - Meliosma wetteraviensis (Ludwig) Mai, endocarp, NM G 8500, core PVJK 234 (depth 62-63 m), x 7. • S - cf. Mastixia lusatica Mai, endocarp, NM G 8501, core PVJK 234 (depth 70-71 m), x 5.5. • T - Symplocos sp., endocarp, NM G 8494, core KU 115 (depth 90-95 m), x 8.5. • U - Vitaceae gen. et sp. indet., seed, NM G 8483, core KU 114 (depth 72-73 m), x 10. • V - cf. Carex sp., fruit, NM G 8489 , core KU 115 (depth 99.2-99.3 m), x 19.5. • W - Stratiotes kaltennordheimensis (Zenker) Keilhack, seed, NM G 8509, core P 542 (depth 91 m), x 5. • X - Sparganium cf. camenzianum Kirchheimer, endocarp, NM G 8506, core KU 127 (depth 75-76 m), x 19. • Y - Potamogetom cf. wiesaensis Kirchheimer, endocarp, NM G 8343, core MR 59 (depth 48.8-50 m), x 9. • Z - Cladium trilobatum Mai, endocarp, NM G 8487, core KU 114 (depth 72-73 m), x 16. • A* Spirematospermum wetzleri (Heer) Chandler emend. Koch \& Friedrich, seed, NM G 8493, opencast mine J. Šverma, x 3.5. 
Vasilis Teodoridis \& Zlatko Kvaček • Palaeobotanical research in the Most Basin
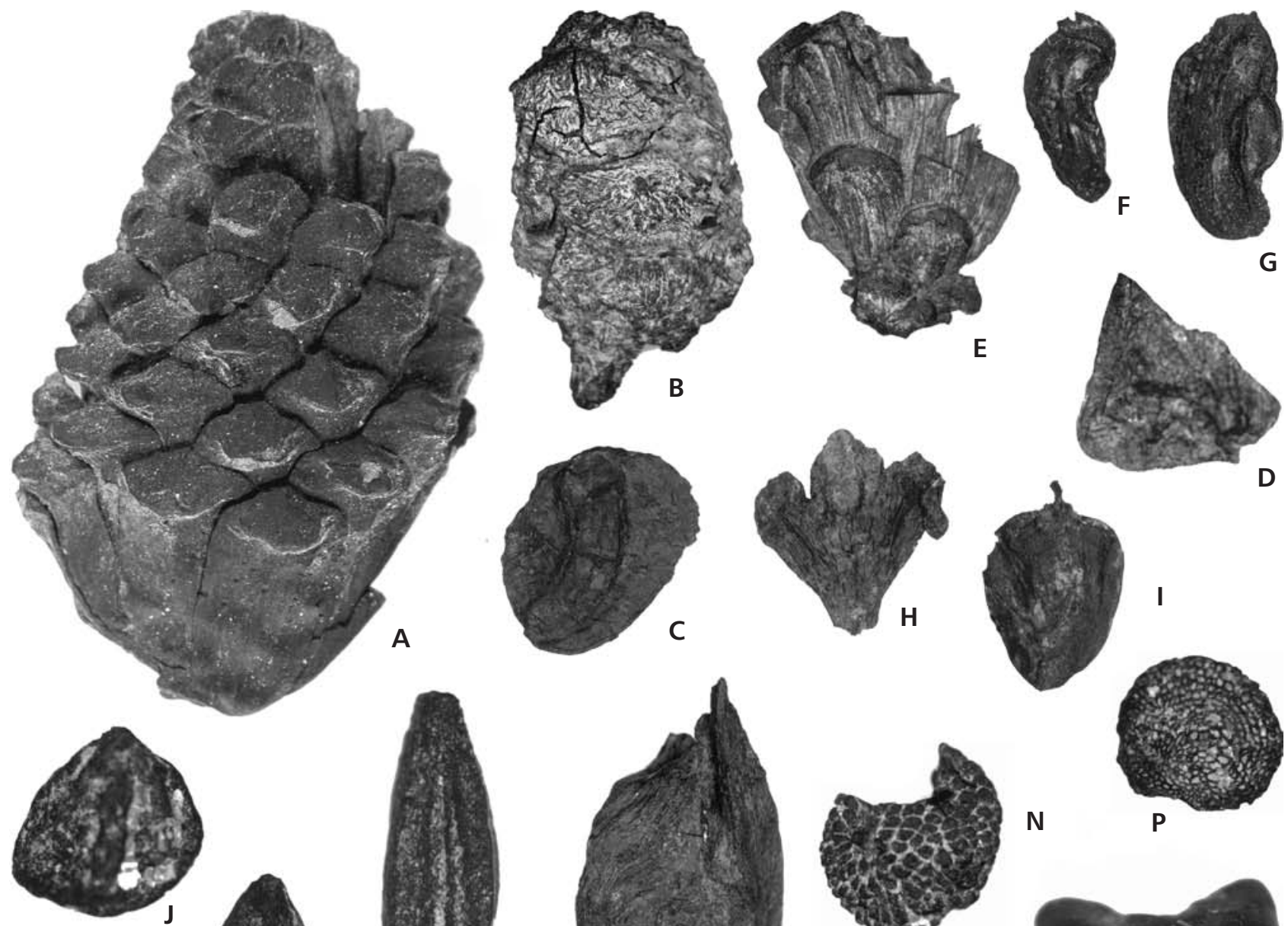

E
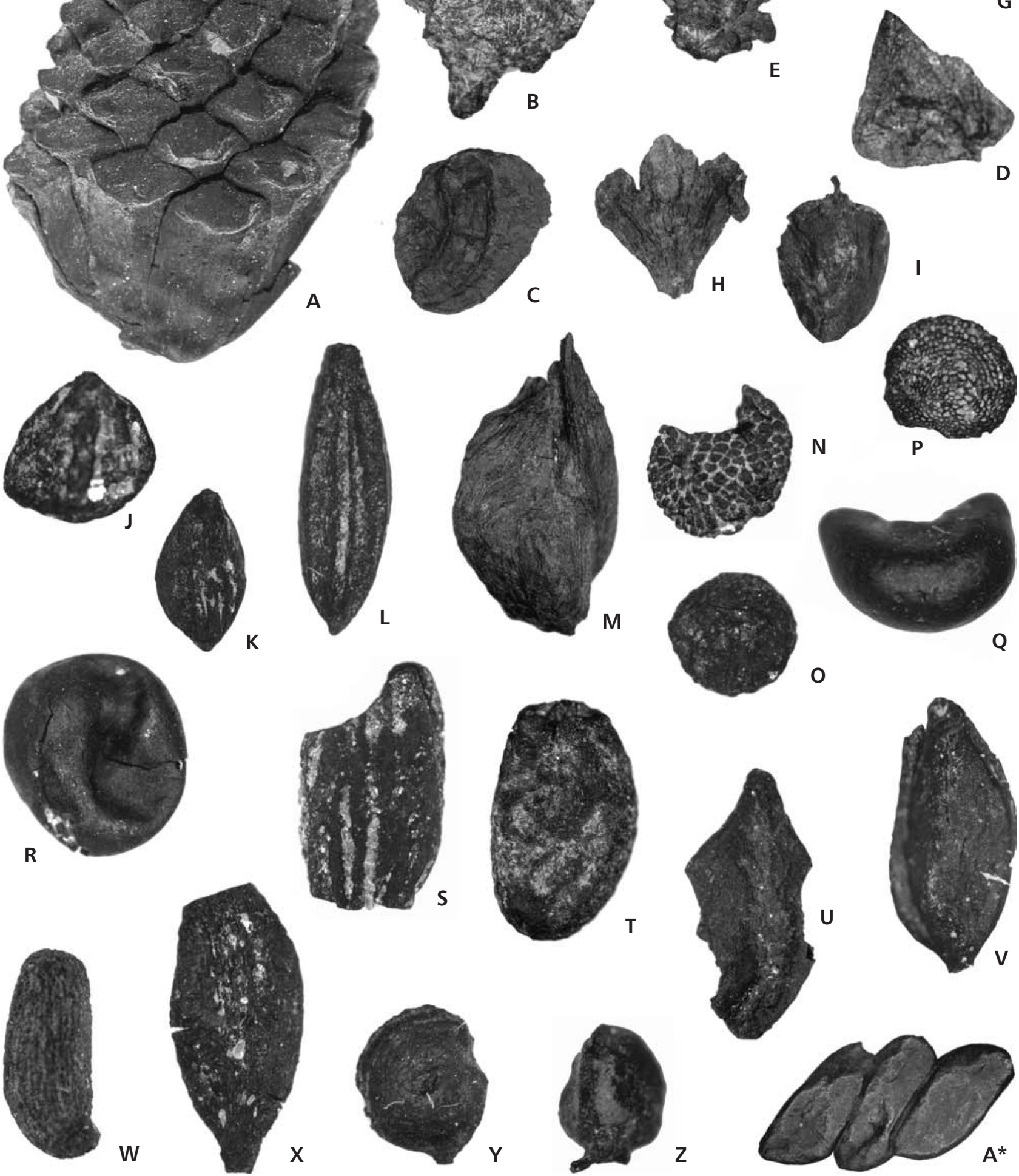

W

X

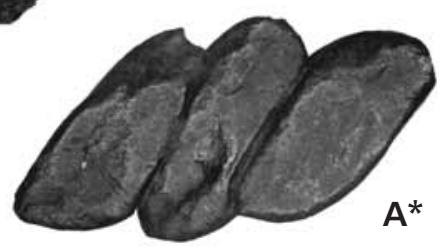


The studied leaf material is housed in the National Museum in Prague (NM), and at the headquarters of the Bílina (DB) and Nástup mines in Tušimice (DN). Cuticle preparations are presently kept at the Institute of Geology and Palaeontology at Charles University in Prague (PRC). The specimens that were described in the ninteenth century have been studied in the collections of the Hungarian Natural History Museum (BP) and the Austrian Geological Survey (Geologische Bundesanstalt) in Vienna (GBA). Similarly, a binocular microscope was used for studying the morphological characters of these specimens. The epidermal anatomy of the leaves have been observed and documented by using an Olympus BX 51 biological microscope in normal transmitted or in polarised light. Currently accepted terminology and applied methods of cuticular analysis follow Hickey (1973) and Kvaček (1985). Hydrofluoric acid was applied to clean inorganic particles in all samples for the cuticular analysis. The chosen fragments were macerated in a drop of Schulze solution or in $\mathrm{SAVO}^{\circledR}$ bleach solution directly on the slide. After reaching the required oxidation, the oxidative reagent was removed by filter paper or fine tissue. The epidermal samples were rinsed with several water drops and then immersed in a $5 \%$ solution of $\mathrm{KOH}$. The carbonized leaf tissue dissolved in the latter solution, and the adaxial and abaxial cuticles were separated mechanically with preparation needles. The resulting cuticles were placed on the slide in a drop of glycerine, covered with a cover glass, and sealed with nail polish. Figures in the text were created as digital pictures using Photoshop 6.0 CZ.

Palaeoenvironmental reconstruction has been attempted using CLAMP (Climate Leaf Analysis Multivariate Program) software, a multivariate statistical technique that decodes the climatic signal inherent in the physiognomy of leaves of woody dicotyledonous plants. The principles and methods of this technique are explained in Wolfe (1990, 1993), Wolfe \& Spicer (1999), and Teodoridis (2003a, p. 67). Symbols for distinguishing vegetative storeys in the environmental reconstruction are used according to Moravec et al. (2000), i.e., E1 (herbs and vines), E2 (shrubs and lianas), E3 (trees under $25 \mathrm{~m}$ high), and E4 (trees over $25 \mathrm{~m}$ high). The following is a list of abbreviations used in the text and tables: MAT - Mean Annual Temperature, WMMT - Warmest Month Mean Temperature, CMMT -
Coldest Month Mean Temperature, MART - Mean Annual Range of Temperature, 3WET - Precipitation during 3 Consecutive Wettest Months, 3DRY - Precipitation during 3 Consecutive Driest Months, MAP - Mean Annual Precipitation.

Comparative extant material was obtained from the following herbaria: Charles University in Prague (PRC), the National Museum in Průhonice (PR), the Faculty of Biology at the State University of Moscow (MW), the Main Botanical Garden of the Russian Academy of Science in Moscow (MHA), and the Botanical Institute of W. Szafer, PAN Krakow (KRAM).

\section{General characteristics and lithostratigraphy of the Most Basin}

The Most Basin is the largest freshwater Cenozoic sedimentary body of the Bohemian Massif. The total thickness of the basin fill (i.e., Most Formation sensu Domácí 1977) in the centre is about $500 \mathrm{~m}$ (Mach in Kvaček et al. 2004). The lignite and brown coal seams that have been worked in the basin constitute the main fuel reserves of the Czech Republic. The base of the Most Formation has been estimated at the Oligocene-Miocene boundary (Bucha et al. 1987, Lotsch et al. 1994, Teodoridis 2002, Suhr 2003). The volcanic rocks underlying the basin fill belong to the Střezov Formation of the local lithostratigraphical scale (Domácí 1977), and consist mostly of deeply weathered lava flows and associated volcanogenic deposits. The basin began to be filled in before the Krušné hory Mts. formed a prominent elevation, and thus the earlier sediment originated from the weathered residua of older rocks from the wider surroundings. Rivers and streams transported pebbles, sand, silt, and clay into the basin. Stream deposits formed a wide belt of fluvial sandy facies ("Hlavačov Gravel and Sand" sensu Váně 1985) in a north-south direction, heading from central Bohemia and entering the basin near Žatec, then leaving the basin probably near Chomutov (Mach in Kvaček et al. 2004, Teodoridis 2004, Rajchl \& Uličný 2005) or across the České středohoří Mts. (Suhr 2003). Similar allochthonous fluvial sediments of limited extent in the NW periphery of the basin, which passed into layers of sub-autochthonous weathering products, were transported

Figure 3. Typical plants of the Břeštany (Preschen) Clay (scale bars $=10 \mathrm{~mm}$ ). $\bullet$ A - Laurophyllum pseudoprinceps Weyland \& Kilpper, leaf, NM G 3894. • B - Nyssa bilinica (Ung.) Z. Kvaček, leaf, NM G 3893. • C - Myrica lignitum (Ung.) Saporta, leaf, NM G 533. • D - Laurophyllum saxonicum Litke, leaf, NM G 4415. • E - Leguminosites sp., leaflet, NM 3766.3. • F - Podocarpium podocarpum (A. Br.) Herendeen, leaflet, NM G 4392. • G Chaneya oeningensis (Unger) Teodoridis \& Z. Kvaček, perianth, NM G 4399. • H - Paliurus tiliaefolius (Ung.) Bůžek, leaf, NM G 4443 . $・$ I - Carya cf. serrifolia (Goepp.) Kräusel, leaflet, NM G 4497. • J - Craigia bronnii (Ung.) Z. Kvaček, Bůžek \& Manchester, fruit valve, lectotype, Unger (1845, pl. 26, fig. 2). $\bullet \mathrm{K}$ - Comptonia difformis (Sternb.) Berry, leaf, BDA 1868.02.75, orig. Ettingshausen (1868, pl. 35, fig. 26). $\bullet$ L - Alnus julianiformis (Sternb.) Z. Kvaček \& Holý, leaf, NM G 1671. • M - Daphnogene polymorpha (A. Br.) Ett., leaf, NM s.n. (1). • N - Acer tricuspidatum Bronn, leaf, BDA 1869.02.94, orig. Ettingshausen (1869, pl. 44, fig. 3). 
Vasilis Teodoridis \& Zlatko Kvaček • Palaeobotanical research in the Most Basin
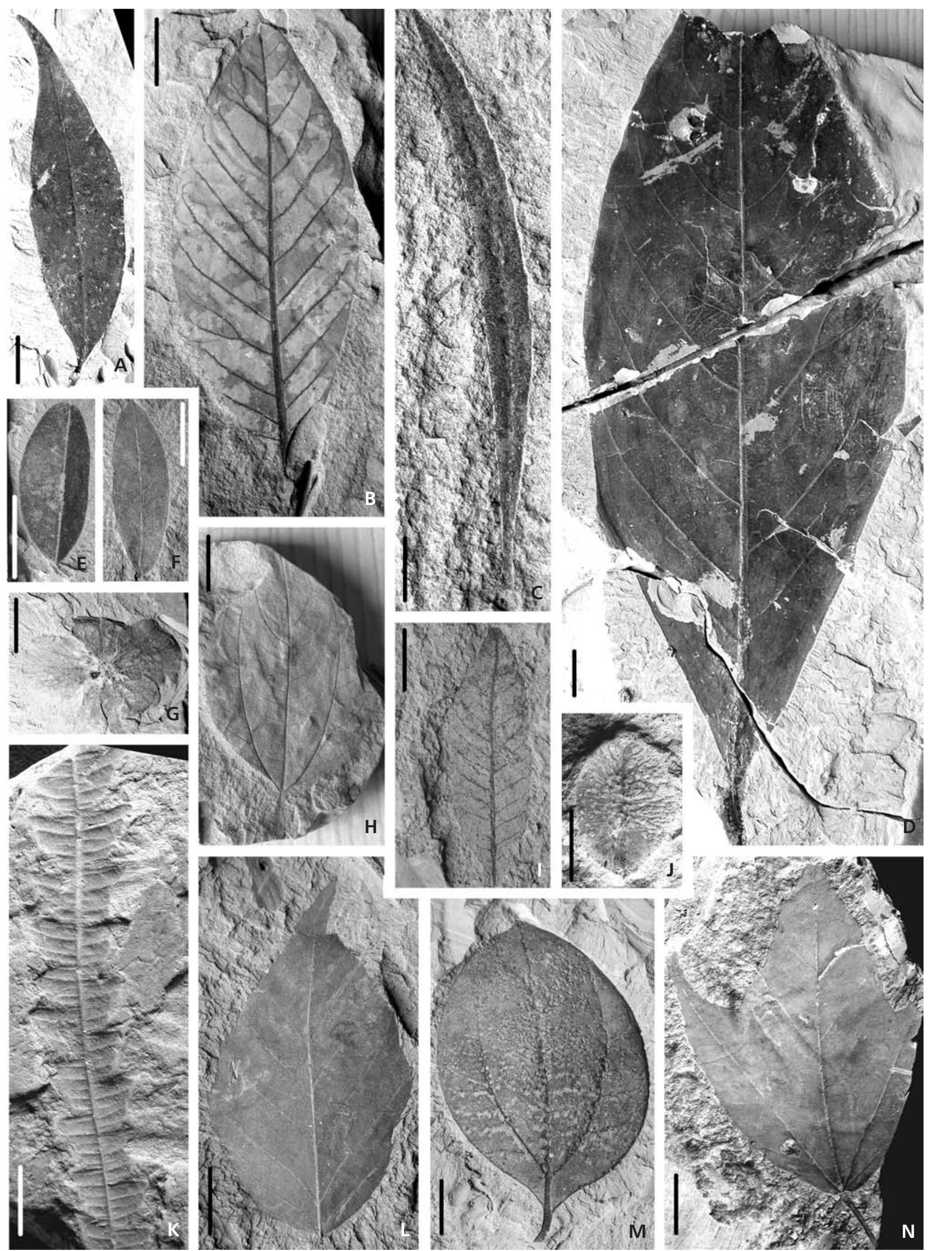
from crystalline rocks, while at the SE periphery sediment was transported from flat volcanic slopes or erosion valleys. These sediments formed the Duchcov Member of the Most Formation (Domácí 1977), previously called the Underlying Formation (see e.g., Elznic 1973). They include well known localities of vertebrate fossils such as Skyřice, the main seam of the Merkur-North mine at the former village of Ahníkov, and the limestone at Tuchořice, all dated to zone MN 3 (Fejfar 1989).

During the Early Miocene, the increasing subsidence of the basin caused the spreading of flatlands with the formation of swamps and shallow lakes. In most parts of the basin, deposits of this period belong to a new unit called the Holešice Member (Domácí 1977). At first, only occasional flooding inundated these wetlands, but they gradually transformed into periodically or steadily inundated local swamps in which plant biomasses accumulated as peat. Individual swamps gradually fused into continuous wide belts along the main stream and its tributaries. This type of landscape had become stable in the basin during the formation of the sediments that became the main coal seam. A stream from the south continued to inundate the basin at Žatec town, and passed northwards across the system of swamps. During flooding events the fluvial facies spread over larger areas of the basin, forming clayey-sandy layers in the peat. The swamp system corresponded mostly to the low moor type. Increased precipitation rarely supplied the swamps more intensely, which is typical of the raised bog regime (Mach in Kvaček et al. 2004).

In the wider environs of Žatec, where most of the streams discharged, sandy deposits prevailed due to the lowering of the river gradient, so that the conditions for peat formation in this area were limited (Václ \& Malkovský 1962). A partial stream later reached the environs of Bílina, where a delta body, called the "Bílina Delta" (see also Hurník 1959, Mach 1997, Dvořák \& Mach 1999, Uličný et al. 2000, Rajchl \& Uličný 2005), originated. This delta was formed by a river that belonged to a large drainage system encompassing NE, E, and SW Bohemia (Malkovský 1995). As stated above, these deposits containing lignite seams and equivalent sandy-clayey delta bodies have been included into the Holešice Member (e.g., Mach 2002), previously called the Coal Seam Formation (see Elznic 1973).

The sudden sinking of the basin base caused progressive flooding, during which the clay and claystone facies ("Overlying Clay" or Overlying Formation sensu Elznic
1973) spread over the swamps and buried the peat layer. These thick strata have been included into the Libkovice Member (Domácí 1977). In the Bílina area, the base of this member is composed of the Břeštany Clay, as suggested by Elznic (1964) and corroborated by exposures in the Bílina opencast mine. Though the Bílina Delta ceased to exist, several small streams entered the basin from the north (e.g., at Jezeří) while others existed at Ústí nad Labem and Žatec. The northern streams transported less sands, but still influenced the character of the clay layers deposited in the lake by bringing traces of mica. Eventually, the lake probably extended well beyond the current limits of the basin. In the area of the Žatec Delta, the Libkovice Member is developed partly in the sandy-clayey facies (Žatec facies sensu Procházka 1954) such as the Př́ivlaky locality. The quartzose sandstone of Hradiště Hill at the Černovice locality (Tschernowitz), now high above the basin on the Krušné hory Mts., may belong to the Libkovice Member (Hurník 1960), although its position below the seam cannot be excluded (e.g., Bůžek 1963, 1984, Hurník 2001).

About 17-18 Ma (Bucha et al. 1987, Malkovský 1995), the lake had become nearly filled with sediment, and shallow swamp conditions were renewed in the environs of Lom in the central part of the basin. This uppermost part of the Most Formation is defined as the Lom Member sensu Domácí (1977), and was originally called the "Lom Formation" (Elznic 1973). The Lom Seam is an incomplete denudation relict of limited extent. It arose in a temporary swamp that was connected with the highest level of the basin fill (Elznic et al. 1998, fig. 15, Hurník 2001, fig. 42).

The lithostratigraphical subdivision employed in this paper adopts the formal units of the International Stratigraphical Nomenclature (see Domácí 1977) and deviates somewhat from the informal system introduced for the needs of practical geology in the basin (Elznic et al. 1986, Malkovský 1987). The previous stratigraphical scales of the Most Basin and their correlation are summarised in Kvaček \& Hurník (2000, p. 23).

\section{Palaeogeography, facies, and dating}

In general, the following facies were widespread during the deposition of the Most Formation. Early stages of the basin are typically flat land with stagnant lakes. In the northwestern parts these landforms became filled with volcanic sediments. Lakes in the central part became filled with clay

Figure 4. New plant fossils from the opencast mine Merkur-North, Tušimice (scale bars = 10 mm). A - Alnus gaudinii (Heer) Knobloch \& Z. Kvaček, leaf, DN 47. • B - Zelkova zelkovifolia (Ung.) Bůžek \& Kotlaba, leaf, DN 25. • C - Trigonobalanopsis rhamnoides (Rossm.) Z. Kvaček \& Walther, DN 18.•D - Trachelospermophyllum sp., leaf, DN 8a.・E- “Celastrus" pyrrhae Ett., leaf, DN 28. • F - cf. Alnus sp., leaf, DN 12.・G - Leguminosites sp., leaflet, DN 19. • H - Fraxinus bilinica (Ung.) Z. Kvaček \& Hurník, leaflet, DN 48. • I - Laurophyllum pseudoprinceps Weyland \& Kilpper, leaf, DN 13. $\mathrm{J}$-Acer pseudomonspessulanum Ung., leaf, DN 33a. 
Vasilis Teodoridis \& Zlatko Kvaček • Palaeobotanical research in the Most Basin
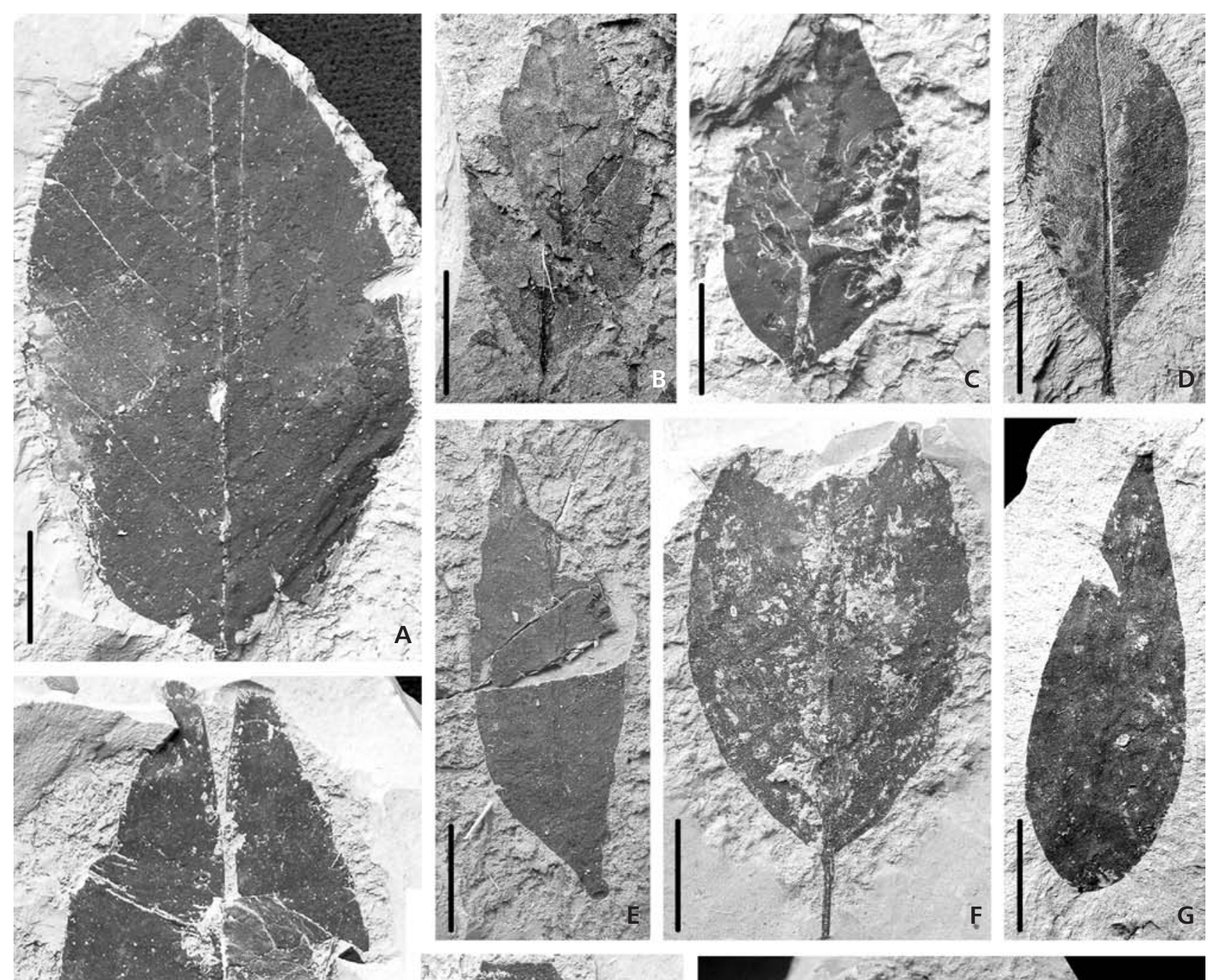

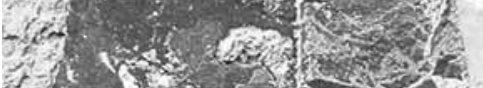

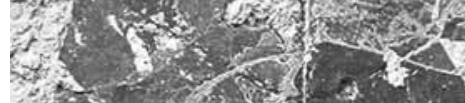
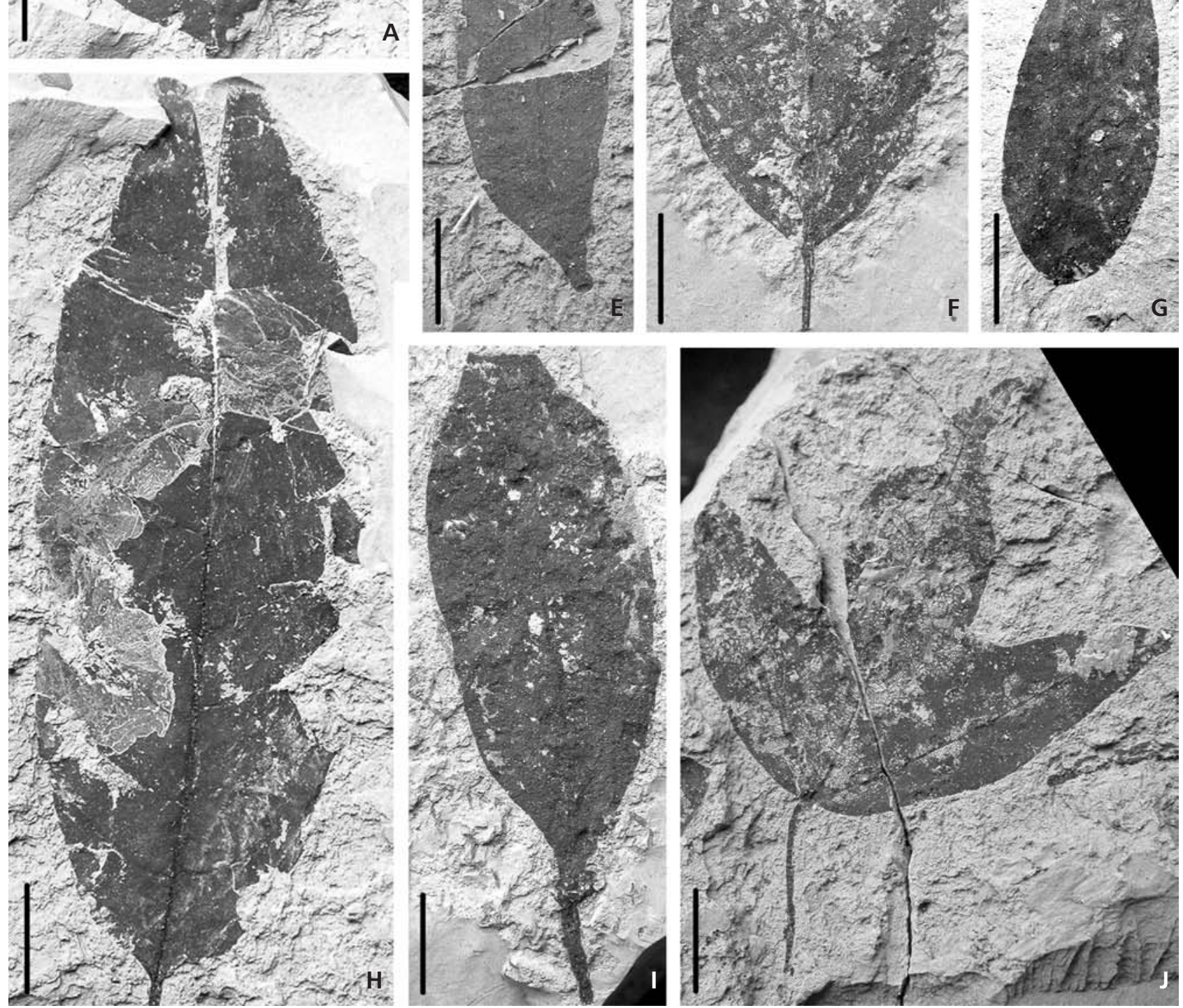
deposits (Elznic 1964), and by fluvial and delta facies near the mouth of the stream coming from central Bohemia ("Hlavačov Gravel and Sand" - Váně 1985, Teodoridis 2002, 2004). The next stage was that of the vast swamps of the Holešice Member, intercalated with clay and sand layers coming from deltas in the Žatec and Bílina areas. We are reluctant to accept the subdivision of this sizeable complex of deposits on the basis of mineralogical and geochemical properties (Elznic et al. 1998), which were diachronically distributed due to local influences. As stated above, a sudden subsidence of the basin transformed the landscape into a large lake in which the clay of the Libkovice Member was deposited. The Libkovice Member is also developed in the delta facies of the Žatec part and in the mica sand and gravel facies on the periphery of the Krušné hory Mts. (e.g., at Jezeří). The most fossil-rich deposits, the facies of the Břeštany Clay, arose during this event. The renewed shallowing of the lake resulted in the accumulation of the Lom Seam in the uppermost part of the basin fill, which was also connected with a small delta in the central part of the basin near the town of Osek (Elznic 1964).

The present paper is focused on the evaluation of the fossil plant record of the Libkovice and Lom Members. The accumulation of these units was only tentatively dated to late Early Miocene according to palaeomagnetic dating (Bucha et al. 1987, Malkovský 1995) and by palaeoflora correlation (Kvaček et al. 2004). The floor of the Main Seam was assigned to mammal zone MN 3 of Early Burdigalian ( Early Eggenburgian) age (see Fejfar 1989, Fejfar \& Kvaček 1993).

\section{Phytogeography and palaeofloristic characteristics}

The composition of plant assemblages is not uniform throughout the basin due to local environmental conditions and evolution through time. Previous studies on the phytogeography of this basin (Hurník 1961) revealed characteristic combinations of taxa that occur in particular parts or horizons. Plant fossils from the Most Formation have so far been assigned to hundreds of taxa, of which about 200 species have been accepted after critical revisions. Woody angiosperms predominate the floral spectrum, while ferns, fern allies, and conifers are far less diversified, though they may compose dominant components of swamp vegetation. In the case of herbs, particularly of monocots, the most reliable studies are based on carpological material because the taxonomic resolution of leaf remains is low.

The flora of the Duchcov Member is not uniform with respect to stratigraphical and palaeogeographical position. The basal seam has been characterised by deciduous broad-leaved elements such as Fagus, Betulaceae, Salicaceae, Hamamelidaceae, and Aceraceae, all of which are known mainly from palynological data (Konzalová 1976). The flora of the "Hlavačov Gravel and Sand" deposits may correspond to this level (see Teodoridis 2002, 2004). An additional plant assemblage comes from the micaceous sandy clay (core JZ 44), and contains evergreen elements (Laurophyllum pseudovillense, Laurophyllum pseudoprinceps) in addition to Pinus and Alnus julianiformis. The quartzose sandstone of Hradiště (Purberg; Engelhardt 1877) at Černovice probably belongs to the same level, although the locality is high up on the Krušné hory Mts., beyond the area of the lignite seam (see Hurník 2001). This assemblage is rich in seed cones of pines, and in principle does not differ from the micaceous clay flora immediately overlying the seam on the Krušné hory Mts. periphery. At the southern periphery of the basin at Tuchořice, the limestone of hot spring origin yielded a unique flora with date palm and other thermophilous plants (Toddalia cf. turovensis, cf. Tectocarya sp.), as well as deciduous broad-leaved trees (Acer tricuspidatum, Celtis lacunose, Ulmus, Zelkova etc. - Kvaček \& Bůžek 1982). Another kind of thermophilous assemblage with Platanus neptuni and Trigonobalanopsis rhamnoides has been recovered from the underlying claystone in the Bílina region (core Je 96).

The flora of the Holešice Member is more diversified in the depocentres of deltas. Both coal and sandy-clayey facies are unusually rich in aquatic plants (Salvinia, Stratiotes etc.). Many woody elements are also shared between both deltas (see Kvaček in Kvaček et al. 2004). Pine fossils are extremely rare. Palms of the Sabal and Calamus type occur mainly in the Most-Bílina area sensu Hurník (1961).

The flora of the lacustrine clay of the Libkovice Member is distinct, probably due to its environmental setting. The mixture of deciduous (Ulmaceae, Betulaceae, Comptonia, Parrotia, Podocarpium) and evergreen

Figure 5. Cuticles of woody plants from the Libkovice Member (scale bars $=100 \mu \mathrm{m})$. $・ \mathrm{~A}-$ Trigonobalanopsis rhamnoides (Rossm.) Z. Kvaček \& Walther, abaxial cuticle, PRC MR 59-1, core MR 59 (depth 129-130 m). • B - Magnolia sp., abaxial cuticle, PRC MR 59-19, core MR 59 (depth 158-159 m). • C - Gordonia hradekensis (Z. Kvaček \& Bůžek) Palamarev \& Bozukov, abaxial cuticle, PRC MR 59-90, core MR 59 (depth 141.2 m). • D - Laurophyllum nechranicense Bůžek \& Z. Kvaček, abaxial cuticle, PRC MR 58-27, core MR 58 (depth $125-126$ m). E - Laurophyllum saxonicum Litke, abaxial cuticle, PRC ČSA 2, opencast mine ČSA. • F - Laurophyllum pseudovillense Z. Kvaček, abaxial cuticle, PRC MR 58-13, core MR 58 (depth 108-109 m). • G - Laurus abchasica (Kolakovskii \& Shakryl) Ferguson, abaxial cuticle, PRC MR 59-5, core MR 59 (depth 129-130 m). • $\mathrm{H}$ - Laurophyllum pseudoprinceps Weyland \& Kilpper, abaxial cuticle, opencast mine Merkur-North, PRC Nástup 50/1. • I - cf. Alnus sp., abaxial cuticle, PRC MR 59-39, core MR 59 (depth 143.2 m). 

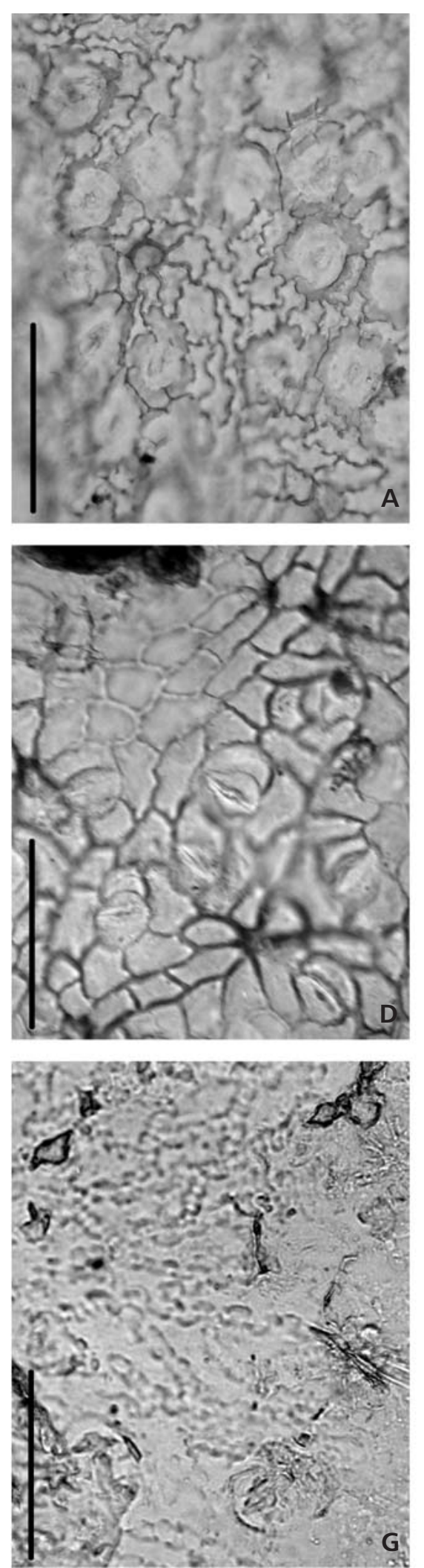
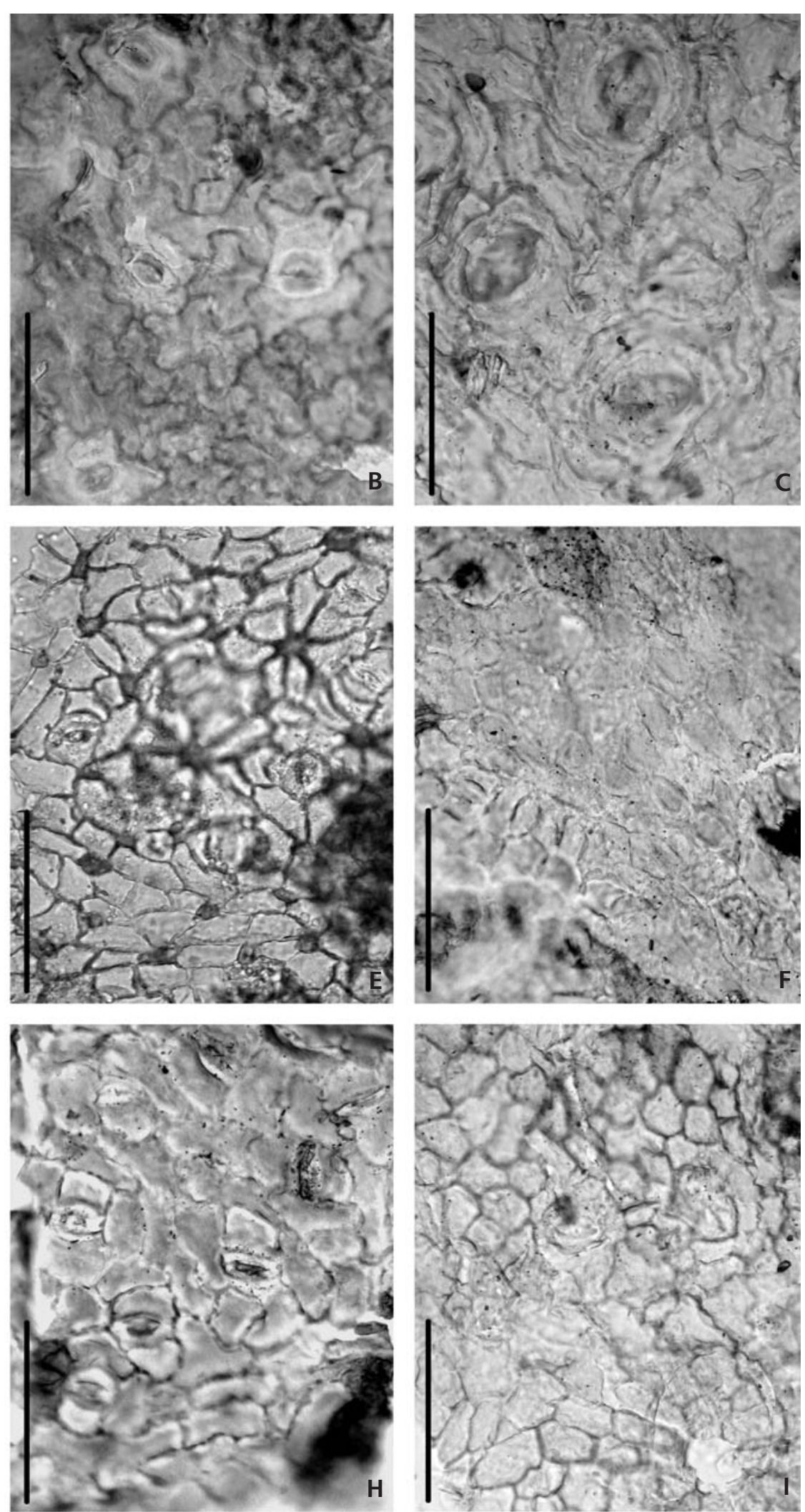
elements (Myrica lignitum, Lauraceae, Trigonobalanopsis), together with common pine fossils, is typical of the Břeštany Clay from the lowest levels of the Libkovice Member. An index fossil Schenkiella credneri has been collected from the upper part of the Bílina section both in the delta facies and the Břsštany Clay (Wójcicki \& Kvaček 2002a). This fossil establishes a link to the Early Miocene Brandis flora of Saxony. Other levels of the Libkovice Member, accessed mostly by cores, have yielded thermophilous assemblages characterised by Lauraceae (Laurophyllum sp. div., Laurus abchasica), Theaceae (Gordonia hradekensis), and Ericaceae (Vaccinioides, Andromediphyllum). Accessory elements such as Cedrelospermum (extinct Ulmaceae), Platanus neptuni, and Quercus kubinyii confirm links to the flora of the Cypris Formation.

The following phytogeographical areas are recognised in our study:

Břeštany area (sensu Hurník 1961). - This area encompasses classic sites of the Břeštany Clay situated northwards from Bílina: Břeštany (Preschen in German), Břežánky (Priesen), Jenišův Újezd (Langugest). In clay pits where clay (Libkovice Member) has been excavated for making ceramics, the underlying sandy facies (Holešice Member) have been exposed. This close proximity caused plant fossils from both levels to be intermixed in older collections under the names of sites such as Bilin or Priesen, Preschen, etc. Previous collectors sometimes mentioned the type of fossiliferous sediment, e.g., sphaerosiderite and plastic clay (see Ettingshausen 1866, 1868, 1869). Only plant fossils embedded in the grey clay facies are considered in our study, while those from the underlying sediments, which belong in our opinion to the Holešice Member and should be ranged into the Most-Bílina area sensu Hurník (1961), have been omitted.

Krušné hory Mts. - Ervěnice area (sensu Hurník 1961). - Drill cores from the Krušné hory Mts. and the centre of the basin have provided most of the newly acquired data. Typical fossiliferous deposits are the micaceous sandy clays to coarse sands (at the NW periphery of the basin) that pass into the firm grey claystone towards the deeper central part. More frequent plant fossils (leaves, fruits, and seeds) are concentrated in the lower levels that usually form the direct roof of the main coal seam (e.g., at Jezeři and Kundratice). Plant fossils are very rare higher in the claystone facies.
Chomutov area. - These deposits are similar to the claystone facies of the Libkovice Member (Chomutov facies sensu Procházka 1954). The Hradiště site (Purberg) at Černovice (Engelhardt 1877) has also tentatively been included by Bůžek \& Kvaček (1982), but may instead belong to the Duchcov Member (see below).

Žatec area. - This area typically includes the sandyclayey facies (Žatec facies sensu Procházka 1954) that extend from the Holešice Member into the Libkovice Member. Only a few sites can be safely ranged into the Libkovice Member, such as Přívlaky (Teodoridis 2004, 2006). The clay (Chomutov) and sandy (Žatec) facies are interfingered, so that the boundaries of these areas overlap (Václ \& Malkovský 1962, Váně 1985).

Ústí nad Labem area. - This area is a NE extension of the Libkovice Member in the claystone (incl. porcelanite) facies (e.g., Modlany, Nechvalice, Český Újezd). The flora is similar to that of the central (Ervěnice) part (see Kvaček \& Hurník 2000, p. 29).

The Lom Member is of limited extent around the town of Lom. Plant fossils have been obtained only from the coal seam and its equivalents, and from cores and an outcrop at Dolní Litvínov. Additional elements of the flora of the Lom Member have been recovered, such as Nyssa cf. haidingeri sensu Knobloch \& Kvaček 1976 (i.e., Nyssa gmelinii), and Hemitrapa heissigii, which typically occur in the Upper Freshwater Molasse in Bavaria, starting with the Late Ottnagian-Karpatian (Meller, personal communication 2005).

The position of the Osek quartzose sandstone and its correlation with the Lom Member, or the other members of the Most Formation, remains problematic (see Hurník 2001, p. 96 vs. Váně 1961, 1999). Plant fossils in this deposit are very rare (e.g., Carya endocarps) and are not considered in our study.

\section{Review of the floras studied}

\section{Libkovice Member}

The flora of the Libkovice Member (Table 1) does not differ profoundly from the previous Holešice Member. Many components are shared by these two members, particularly in the lowermost part (the Břeštany Clay and the sandy

Figure 6. Cuticles of woody plants from the Libkovice Member (scale bars $=100 \mu \mathrm{m})$. $\bullet$ A - Myrica lignitum (Ung.) Saporta, abaxial cuticle, PRC MR 58-12, core MR 58 (depth 110-111 m). • B - Oleinites sp., abaxial cuticle, PRC MR 58-16, core MR 58 (depth $110-111$ m). $\bullet$ C - Platanus neptuni (Ett.) Bůžek, Holý \& Z. Kvaček, abaxial cuticle, PRC CSA 46, opencast mine ČSA.・D - Quercus kubinyii (Ett.) Czeczott, adaxial cuticle, PRC MR 59-84, core MR 59 (depth 99-135 m). • E - Quercus kubinyii (Ett.) Czeczott, abaxial cuticle, PRC MR 59-84, core MR 59 (depth 99-135 m). • F - Symplocos volkeri Z. Kvaček, abaxial cuticle, PRC LiH13-8, core LiH 13 (depth 42-57 m). G - Vaccinioides lusatica Z. Kvaček \& Walther, abaxial cuticle, PRC CN 85-2, core CN 85 (depth 54.5 m). $\bullet$ H - Andromediphyllum sp., abaxial cuticle, PRC CSA 12, opencast mine ČSA. $\bullet$ I - Hamamelidaceae gen. et sp. indet., abaxial cuticle, PRC Al 55-3, core Al 55 (depth 97.7 m). 

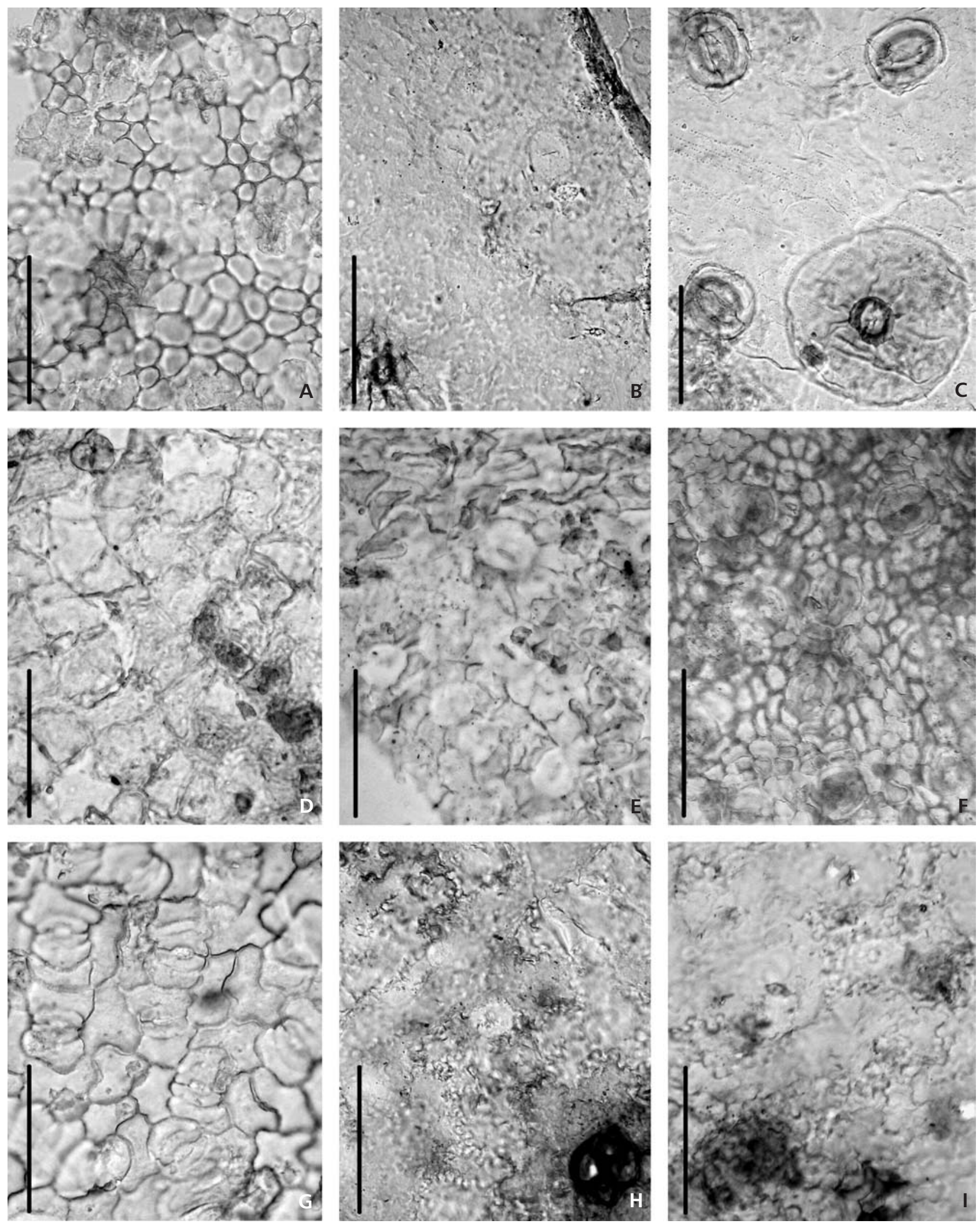
Table 1. Summary of the floral composition of the localities studied from the Libkovice Member (see also Appendix). - Abbreviations: B (bract), C (cone), Ec (endocarp), Ex (exocarp), F (fruit), L (leaf), S (seed), Sp (spore), BA (Bílina area), ÚA (Ústí nad Labem area), 1 - Břeštany Clay, 2 - KU 108, 3-KU 114, 4-KU 115, 5 - KU 116, 6-KU 127, 7 - JZ 42, 8 - JZ 44, 9 - JZ 47, 10 - CN 54, 11 - Al 55, 12 - PVJK 234, 13 - HJi 142, 14 - Ja 28, 15 - LiH 13, 16 - Lb 188, 17 - P 542, 18 - M 541, 19 - MR 58, 20 - MR 59, 21 - LOM 16, 22 - ČSA mine, 23 - J. Šverma mine, 24 - Merkur-North mine, 25 Nechranice, 26 - Čermníky, 27 - Soběsuky, 28 - Dolany, 29 - Přívlaky, 30 - Nechvalice.

\begin{tabular}{|c|c|c|c|c|c|c|c|c|c|c|c|c|c|c|c|c|c|c|c|c|c|c|c|c|c|c|c|c|c|c|c|}
\hline \multirow{3}{*}{ Taxa } & \multirow{3}{*}{ 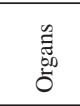 } & \multicolumn{30}{|c|}{ Cores/Localities } \\
\hline & & BA & & & & & & & & & Kru & ı̌nné & hory & Mts & $-\mathrm{E}$ & rvěn & ce a & & & & & & & & & & Chon & nutor & are & & ÚA \\
\hline & & 1 & 2 & 3 & 4 & 5 & 6 & 7 & 8 & 9 & 10 & 11 & 12 & 13 & 14 & 15 & 16 & 17 & 18 & 19 & 20 & 21 & 22 & 23 & 24 & 25 & 26 & 27 & 28 & 29 & 30 \\
\hline Acer angustilobum & $\mathrm{L}$ & + & - & - & - & - & - & - & - & - & - & - & - & - & - & - & - & - & - & - & - & - & - & - & - & - & - & - & - & + & - \\
\hline Acer pseudomonspessulanum & $\mathrm{L}$ & + & - & - & - & - & - & - & - & - & - & - & - & - & - & - & - & - & - & - & - & - & - & - & + & - & - & - & - & - & - \\
\hline Acer sp. & $\mathrm{F}$ & - & - & - & - & - & - & - & - & - & - & - & - & - & - & - & - & - & - & + & - & - & - & - & + & - & + & + & + & - & - \\
\hline Acer tricuspidatum & $\mathrm{L}$ & + & - & - & + & - & - & - & - & - & - & - & - & + & + & + & - & - & - & - & - & - & - & - & + & - & - & - & - & - & - \\
\hline Alnus gaudinii & $\mathrm{L}$ & + & - & - & + & - & - & - & - & - & - & - & - & $?$ & - & - & - & - & - & + & - & $?$ & + & - & + & - & - & - & - & - & - \\
\hline Alnus julianiformis & $\mathrm{L}$ & + & - & - & + & - & $?$ & + & + & - & + & - & - & + & - & - & - & - & - & - & - & - & + & - & + & - & - & - & - & - & + \\
\hline Alnus lusatica & $\mathrm{F}, \mathrm{B}$ & - & - & - & - & - & - & - & - & - & - & - & - & - & - & - & - & - & - & - & - & - & - & + & - & - & - & - & - & - & - \\
\hline Alnus menzelii & $\mathrm{L}$ & + & - & - & - & - & - & - & - & - & - & - & - & - & - & - & - & - & - & - & - & - & - & - & - & - & - & - & - & - & - \\
\hline cf. Alnus sp. & $\mathrm{L}$ & - & - & - & - & - & - & - & - & - & - & - & - & - & - & - & - & - & - & + & + & - & - & - & - & - & - & - & - & - & - \\
\hline Alnus sp. & $\mathrm{L}$ & - & - & - & - & - & - & - & - & - & - & - & - & - & - & - & - & - & - & - & - & - & - & - & + & - & - & - & - & + & - \\
\hline Andromediphyllum sp. $\mathrm{n}$. & $\mathrm{L}$ & - & - & - & - & - & - & - & - & - & - & - & - & - & - & - & - & - & - & + & - & - & + & - & - & - & - & - & - & - & - \\
\hline Azolla aff. nana & $\mathrm{Sp}$ & - & - & - & - & - & - & - & - & - & - & - & - & - & - & - & + & - & - & - & - & - & - & - & - & - & - & - & - & - & - \\
\hline Azolla aff. rossica & $\mathrm{Sp}$ & - & - & - & - & - & - & - & - & - & - & - & - & - & - & - & + & - & - & - & - & - & - & - & - & - & - & - & - & - & - \\
\hline Azolla aff. ventricosa & $\mathrm{Sp}$ & - & - & - & - & - & - & - & - & - & - & - & - & - & - & - & + & - & - & - & - & - & - & - & - & - & - & - & - & - & - \\
\hline Berchemia multinervis & $\mathrm{L}$ & + & - & - & - & - & - & - & - & - & - & - & - & - & - & - & - & - & - & - & - & - & - & - & - & - & - & - & - & - & - \\
\hline Betula sp. & $\mathrm{L}$ & + & - & - & - & - & - & - & - & - & - & - & - & - & - & - & - & - & - & - & - & - & - & - & - & - & - & - & - & + & - \\
\hline cf. Carex sp. & $\mathrm{F}$ & - & - & - & + & - & - & - & - & - & - & - & - & - & - & - & - & - & - & - & - & - & - & - & - & - & - & - & - & - & - \\
\hline Carya cf. serrifolia & $\mathrm{L}$ & + & - & - & - & - & - & - & - & - & - & - & - & - & - & - & - & - & - & - & - & - & - & - & + & - & - & - & - & + & - \\
\hline Cedrelospermum sp. & $\mathrm{L}$ & - & - & - & - & - & - & - & - & - & - & - & - & - & - & - & - & - & - & + & - & - & - & - & - & - & - & - & - & - & - \\
\hline "Celastrus" pyrrhae & $\mathrm{L}$ & + & - & - & - & - & - & - & - & - & - & - & - & - & - & - & - & - & - & - & - & - & - & - & + & - & - & - & - & - & - \\
\hline Cercidiphyllum crenatu & $\mathrm{L}$ & + & - & - & - & - & - & - & - & - & - & - & - & - & - & - & - & - & - & - & - & - & - & - & - & - & - & - & - & - & - \\
\hline Cladiocarya sp. & $\mathrm{F}$ & - & - & - & - & - & - & - & - & - & - & - & - & - & - & - & - & - & - & + & - & - & - & - & - & - & - & - & - & - & - \\
\hline Cladium trilobatum & $\mathrm{F}$ & - & - & + & - & - & - & - & - & - & - & - & - & - & - & - & - & - & - & - & - & - & - & - & - & - & - & - & - & - & - \\
\hline Comptonia difformis & $\mathrm{L}$ & + & + & - & + & - & + & - & - & - & - & - & - & - & - & - & - & - & - & - & - & - & + & - & + & + & + & - & + & + & + \\
\hline Comptonia goniocarpa & Ec & - & - & - & - & - & + & - & - & - & - & - & - & - & - & - & - & - & - & - & - & - & - & - & - & - & - & - & - & - & - \\
\hline Comptonia longistyla & Ec & - & - & - & - & - & + & - & - & - & - & - & - & - & - & - & - & - & - & - & - & - & - & - & - & - & - & - & - & - & - \\
\hline Craigia bronnii & $\mathrm{F}$ & + & - & - & - & - & - & - & - & - & - & - & - & - & - & - & - & - & - & - & - & - & - & - & + & - & + & - & - & - & - \\
\hline Daphnog & $\mathrm{L}$ & + & - & - & + & - & - & - & - & - & + & - & - & + & + & + & - & - & - & + & + & - & + & - & + & - & + & - & - & - & - \\
\hline Decodon sp. & $\mathrm{L}$ & + & - & - & - & - & - & - & - & - & - & - & - & - & - & - & - & - & - & - & - & - & - & - & - & - & - & - & - & - & - \\
\hline Dicotylophyllum sp. n. & $\mathrm{L}$ & + & - & - & - & - & - & - & - & - & - & - & - & + & - & - & - & - & - & - & - & - & - & - & + & - & - & - & - & + & - \\
\hline cf. Diospyros brachysepala & $\mathrm{L}$ & - & - & - & - & - & - & - & - & - & - & - & - & - & - & - & - & - & - & - & - & - & - & - & - & - & - & - & - & + & - \\
\hline Diversiphyllum aesculapi & $\mathrm{L}$ & + & - & - & - & - & - & - & - & - & - & - & - & - & - & - & - & - & - & - & - & - & - & - & - & - & - & - & - & - & - \\
\hline Dombeyopsis lobata & $\mathrm{L}$ & + & - & - & - & - & - & - & - & - & - & - & - & - & - & - & - & - & - & - & - & - & - & - & - & - & - & - & - & - & - \\
\hline Dulichium sp. & $\mathrm{F}$ & - & - & - & - & - & + & - & - & - & - & - & - & - & - & - & - & - & - & - & - & - & - & - & - & - & - & - & - & - & - \\
\hline Engelhardia macroptera & B & + & - & - & - & - & - & - & - & - & - & - & - & - & - & - & - & - & - & + & + & - & - & - & - & - & - & - & - & - & - \\
\hline Engelhardia orsbergensis & $\mathrm{L}$ & + & - & - & - & - & - & - & - & - & - & - & - & - & - & + & - & - & - & + & + & - & - & - & + & - & - & - & - & - & + \\
\hline Eurya stigmosa & $\mathrm{S}$ & - & - & - & - & - & + & - & - & - & - & - & - & - & - & - & - & - & - & - & - & - & - & - & - & - & - & - & - & - & - \\
\hline Fagus saxonica & $\mathrm{L}$ & - & - & - & - & - & - & - & - & - & - & - & - & - & - & - & - & - & - & - & - & - & - & - & - & - & - & - & - & + & - \\
\hline "Ficus" truncata & $\mathrm{L}$ & + & - & - & - & - & - & - & - & - & - & - & - & - & - & - & - & - & - & - & - & - & - & - & - & - & - & - & - & - & - \\
\hline Fraxinus bilinica & $\mathrm{L}$ & + & - & - & - & - & - & - & - & - & - & - & - & - & - & - & - & - & - & - & - & - & - & - & + & - & - & - & - & - & - \\
\hline Fraxinus macroptera & $\mathrm{F}$ & + & - & - & - & - & - & - & - & - & - & - & - & - & - & - & - & - & - & - & - & - & - & - & - & - & - & - & - & - & - \\
\hline Glyptostrobus europaeus & , S, L & + & - & - & + & - & + & - & - & - & + & - & - & - & - & + & - & + & - & + & - & - & - & - & + & + & + & - & - & - & + \\
\hline Gordonia hradekensis & $\mathrm{L}$ & - & - & - & - & - & - & - & - & - & - & - & - & - & - & - & - & - & - & + & + & - & - & - & - & - & - & - & - & - & - \\
\hline Hamamelidaceae indet. & $\mathrm{L}$ & - & - & - & - & - & - & - & - & - & - & + & - & - & - & - & - & - & - & - & - & - & - & - & - & - & - & - & - & - & - \\
\hline Chaneya oehningensis & $\mathrm{F}$ & + & - & - & - & - & - & - & - & - & - & - & - & - & - & - & - & - & - & - & - & - & - & - & - & - & - & - & - & - & - \\
\hline Juglans sp. & $\mathrm{L}$ & + & - & - & - & - & - & - & - & - & - & - & - & - & - & - & - & - & - & - & - & - & - & - & - & - & - & - & - & - & - \\
\hline Laurophyllum nechranicense & $\mathrm{L}$ & - & - & - & - & - & - & + & - & - & - & - & - & + & - & - & - & - & - & + & - & - & - & - & - & - & - & - & - & - & - \\
\hline Laurophyllum pseudoprinceps & $\mathrm{L}$ & + & - & - & + & - & - & + & + & + & - & - & - & + & + & + & - & - & - & + & + & - & - & - & + & - & $?$ & - & - & - & - \\
\hline Laurophyllum pseudovillense & $\mathrm{L}$ & - & - & - & + & - & - & - & + & - & - & - & - & + & - & + & - & - & - & + & + & - & - & - & - & - & - & - & - & - & - \\
\hline Laurophyllum saxonicum & $\mathrm{L}$ & + & - & - & - & - & - & - & - & - & - & - & - & - & - & - & - & - & - & + & - & - & - & - & - & - & - & - & - & - & - \\
\hline Laurophyllum sp. 1 & $\mathrm{~L}$ & + & - & - & - & - & - & - & - & - & - & - & - & - & - & - & - & - & - & - & - & - & - & - & - & - & - & - & - & - & - \\
\hline Laurophyllum sp. 2 & $\mathrm{~L}$ & + & - & - & - & - & - & - & - & - & - & - & - & - & - & - & - & - & - & - & - & - & - & - & - & - & - & - & - & - & - \\
\hline Laurus abchasica & $\mathrm{L}$ & - & - & - & - & - & - & - & - & - & - & - & - & - & - & - & - & - & - & - & + & - & - & - & - & - & - & - & - & - & - \\
\hline Leguminosites sp. 1 & $\mathrm{~L}$ & - & - & - & - & - & - & - & - & - & - & - & - & - & - & - & - & - & - & + & + & + & - & - & + & - & - & - & - & - & + \\
\hline Leguminosites sp. 2 & $\mathrm{~L}$ & - & - & - & - & - & - & - & - & - & - & - & - & - & - & - & - & - & - & - & - & - & - & - & + & - & - & - & - & - & + \\
\hline Liquidambar europaea & $\mathrm{L}$ & + & - & - & - & - & - & - & - & - & - & - & - & - & - & - & - & - & - & - & - & - & - & - & - & - & - & - & - & + & - \\
\hline Lygodium gaudinii & $\mathrm{L}$ & - & - & - & - & - & - & - & - & - & - & - & - & - & - & - & - & - & - & + & - & - & - & - & - & - & - & - & - & - & - \\
\hline
\end{tabular}


Table 1, continued.

\begin{tabular}{|c|c|c|c|c|c|c|c|c|c|c|c|c|c|c|c|c|c|c|c|c|c|c|c|c|c|c|c|c|c|c|c|}
\hline \multirow{3}{*}{ Taxa } & & & & & & & & & & & & & & & & & & & & & & & & & & & & & & & \\
\hline & 㤐 & BA & & & & & & & & & & fné l & ory & Mts. & $-\mathrm{Er}_{1}$ & rěn & ce & & & & & & & & & & hom & utov & area & & \\
\hline & & 1 & 2 & 3 & 4 & 5 & 6 & 7 & 8 & 9 & 10 & 11 & 12 & 13 & 14 & 15 & 16 & 17 & 18 & 19 & 20 & 21 & 22 & 23 & 24 & 25 & & 27 & 28 & 29 & \\
\hline Magnolia sp. & $\mathrm{L}$ & - & - & - & - & - & - & - & & - & - & - & - & - & - & & - & 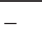 & - & + & - & - & - & - & - & - & - & - & - & - & - \\
\hline Mahonia bilinica & $\mathrm{L}$ & + & - & - & - & - & - & - & - & - & - & - & - & - & - & - & - & - & - & - & - & - & - & - & - & - & - & - & - & - & - \\
\hline Mastixia lusatica & Ec & - & - & - & - & - & - & - & - & - & - & - & + & - & - & & - & - & - & - & - & - & - & - & - & - & - & - & - & - & \\
\hline Ieliosma wetterav & $\mathrm{E}$ & - & - & - & - & - & + & - & - & - & - & - & + & - & - & - & - & - & - & - & - & - & - & - & - & - & - & - & - & - & \\
\hline yrica ceriferifor & & - & - & - & - & + & + & - & - & - & - & - & + & - & - & - & - & - & - & - & - & - & - & - & - & - & - & - & - & - & \\
\hline & & + & + & - & + & - & + & - & $t$ & - & - & + & - & + & + & + & - & - & - & + & + & + & - & - & + & - & + & - & - & - & \\
\hline & E & - & - & - & + & + & - & - & - & - & - & - & - & - & - & - & - & - & - & - & - & - & - & - & - & - & - & - & - & - & - \\
\hline & & - & - & - & - & - & - & - & - & - & - & - & - & - & - & _ & - & - & - & - & - & - & - & - & - & - & - & - & - & + & - \\
\hline is & Ec & - & + & - & - & - & + & - & - & - & - & - & + & - & - & - & - & - & - & - & - & - & - & + & - & - & - & - & - & - & - \\
\hline$S S S$ & L & + & - & - & - & - & - & - & - & - & - & - & - & - & - & - & - & - & - & - & - & - & - & - & - & - & - & - & - & - & - \\
\hline & $\mathrm{Ec}$ & + & - & - & - & - & - & - & - & - & - & - & - & - & - & - & - & - & - & - & - & - & - & - & - & - & - & - & - & - & - \\
\hline$n_{0}+2$ & $\mathrm{~L}$ & - & - & - & - & - & - & - & - & - & - & - & - & - & - & - & - & - & - & + & - & - & - & - & - & - & - & - & - & - & - \\
\hline Saluur & F & + & - & - & - & - & - & - & - & - & - & - & - & - & - & - & - & - & - & - & - & - & - & - & - & - & - & - & - & - & - \\
\hline te & L & + & - & - & - & - & - & - & - & - & - & - & - & - & - & - & - & - & - & - & - & - & - & - & - & - & - & - & - & - & \\
\hline & & + & - & - & - & - & - & - & - & - & - & - & - & - & - & - & - & - & - & - & - & - & - & - & - & - & - & - & - & + & - \\
\hline & L & + & - & - & - & - & - & - & - & - & - & - & - & - & - & - & - & - & - & - & - & - & - & - & - & - & - & - & - & - & - \\
\hline sar & C & + & - & + & + & + & - & - & - & - & - & - & + & - & - & - & - & - & - & - & - & - & - & - & - & - & - & - & - & - & - \\
\hline & C & + & - & - & - & - & - & - & - & - & - & - & - & - & - & - & - & - & - & - & - & - & - & - & - & - & - & - & - & - & - \\
\hline & L & + & - & - & - & - & - & - & - & - & - & - & - & - & - & - & - & - & - & - & - & - & - & - & - & - & - & - & - & - & + \\
\hline & L & - & ? & - & + & + & - & + & + & + & + & - & - & + & ? & + & - & - & - & + & + & - & + & - & + & - & + & - & - & - & - \\
\hline & C & - & - & + & + & + & - & - & - & - & - & - & + & - & - & - & - & - & - & - & - & - & - & - & - & - & - & - & - & - & - \\
\hline nent & L & - & - & - & - & - & - & - & - & - & - & - & - & - & - & - & - & - & - & + & - & - & - & - & - & - & - & - & - & - & - \\
\hline & L & + & - & - & - & - & - & - & - & - & - & - & - & - & - & - & - & - & - & - & - & - & - & - & - & - & - & - & - & - & \\
\hline & L & + & - & - & - & - & - & - & - & - & - & - & - & - & - & - & - & - & - & - & - & - & - & - & - & - & - & - & - & + & \\
\hline & L & + & - & - & - & - & - & - & - & - & - & - & - & - & - & - & - & - & - & - & - & - & - & - & - & - & - & - & - & + & - \\
\hline & I & - & - & - & - & - & - & - & - & - & - & - & - & - & - & - & - & - & - & - & - & - & - & - & - & - & - & - & - & + & - \\
\hline & $\mathrm{Ec}$ & - & - & - & + & - & - & - & - & - & - & - & - & - & - & - & - & - & - & - & + & - & - & - & - & - & - & - & - & - & - \\
\hline & L & - & - & - & - & - & - & - & - & - & - & - & - & - & - & - & - & - & - & - & - & - & - & - & - & - & - & - & - & - & - \\
\hline & $\mathrm{F}$ & - & - & - & - & + & - & - & - & - & - & - & - & - & - & - & - & - & - & - & - & - & - & - & - & - & - & - & - & - & - \\
\hline Dyn & L & + & - & - & - & - & - & - & - & - & - & - & - & - & - & - & - & - & - & - & - & - & - & - & - & - & - & - & - & - & - \\
\hline Ougs & $S, L$ & - & - & - & - & - & + & - & - & - & - & - & - & - & - & - & - & + & + & - & - & - & - & + & - & - & - & - & - & - & \\
\hline & $\mathrm{L}$ & - & - & - & - & - & - & - & - & + & - & - & - & - & - & - & - & - & - & + & + & + & - & - & - & - & - & - & - & - & \\
\hline & L & + & - & - & - & - & - & - & - & - & - & - & - & ? & - & + & - & - & - & - & - & - & - & - & + & - & + & - & - & - & \\
\hline & L & - & - & - & - & - & - & - & - & - & - & - & - & - & - & - & - & - & - & - & - & - & - & - & + & - & + & - & - & - & \\
\hline & L & + & - & - & - & - & - & - & - & - & - & - & - & - & - & - & - & - & - & - & - & - & - & - & + & - & - & - & - & + & - \\
\hline & L & + & - & - & - & - & - & - & - & - & - & - & - & - & - & - & - & - & - & - & - & - & - & - & - & - & - & - & - & - & - \\
\hline & & + & - & - & - & - & - & - & - & - & - & - & - & - & - & - & - & - & - & - & - & - & - & - & - & - & - & - & - & + & - \\
\hline & & + & - & - & - & - & - & - & & - & - & - & - & - & - & - & - & - & - & - & - & - & - & + & - & - & - & - & - & - & \\
\hline "S $S a t$ & I & ? & - & - & - & - & - & - & & - & - & - & - & - & - & - & - & - & - & - & - & - & - & - & - & - & - & - & - & + & - \\
\hline Felat & $\mathrm{S}_{\mathrm{I}}$ & - & - & - & - & - & - & - & - & - & - & - & + & - & - & - & - & - & - & - & - & - & - & - & - & - & - & - & - & - & - \\
\hline & $S$ & - & - & - & + & - & - & - & - & - & - & - & + & - & - & - & - & - & - & - & - & - & - & - & - & - & - & - & - & - & \\
\hline & & + & - & - & - & - & - & - & - & - & - & - & - & - & - & - & - & - & - & - & - & - & - & - & - & - & - & - & - & - & \\
\hline & & - & - & - & - & - & + & - & - & - & - & - & - & - & - & - & - & - & - & - & - & - & - & - & - & - & - & - & - & - & - \\
\hline & $S$ & - & - & - & - & - & - & - & - & - & - & - & - & - & - & - & - & - & - & - & - & - & - & + & - & - & - & - & - & - & - \\
\hline & & - & - & - & - & - & - & - & - & - & - & - & - & - & - & - & - & + & - & - & - & - & - & - & - & - & - & - & - & - & - \\
\hline & & - & - & - & + & - & - & - & & - & - & - & - & - & - & - & - & - & - & - & - & - & - & - & - & - & - & - & - & - & \\
\hline & & - & - & - & - & - & - & - & & - & - & - & - & - & - & & - & - & - & - & - & - & - & - & - & - & - & - & - & - & \\
\hline & & + & - & - & - & - & - & - & & - & - & - & - & - & - & - & - & - & - & - & - & - & - & + & - & - & - & - & - & + & + \\
\hline & & - & - & - & - & - & + & - & 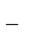 & - & - & - & - & - & - & - & - & - & - & - & - & - & - & - & + & - & - & - & - & - & \\
\hline & & + & - & - & - & - & - & - & 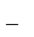 & - & - & - & - & - & - & - & - & - & - & - & - & - & - & - & - & - & - & - & - & - & \\
\hline & & + & - & - & - & - & - & - & 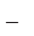 & - & - & - & - & - & - & - & - & - & - & - & - & - & - & - & - & - & - & - & - & - & \\
\hline & S & - & + & + & - & - & - & - & - & - & - & - & + & - & - & - & - & - & - & - & - & - & - & - & - & - & - & - & - & - & \\
\hline & L & - & - & - & - & - & - & - & 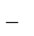 & - & - & - & - & - & - & - & - & - & - & - & - & - & - & - & - & - & - & - & - & + & - \\
\hline & L & - & - & - & - & - & - & - & - & - & - & - & - & - & - & - & - & - & - & - & - & - & - & - & + & - & - & - & - & - & \\
\hline & $F$ & - & - & - & - & - & - & - & & - & - & - & - & - & - & - & - & - & - & - & - & - & - & + & & - & - & - & - & - & \\
\hline & L & + & - & - & - & - & - & - & & - & - & - & - & - & - & - & - & - & - & + & + & - & - & - & + & - & - & - & - & - & \\
\hline & $\mathrm{L}$ & + & - & - & - & - & - & - & & - & - & - & - & - & - & - & - & - & - & - & - & - & - & - & - & - & - & + & + & + & \\
\hline & & - & - & - & _ & - & - & - & & - & & - & - & - & & - & - & - & - & - & - & - & + & - & - & - & - & - & - & - & \\
\hline & & - & - & + & - & - & - & - & & - & & - & - & - & & - & - & - & - & - & - & - & - & - & - & - & - & - & - & - & \\
\hline & $\mathrm{L}$ & + & - & - & - & - & - & - & & - & & - & - & - & & - & - & - & - & - & - & - & - & - & - & - & - & - & - & + & \\
\hline$l k o$ & & + & 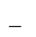 & & _ & - & & - & & & & & & & & 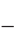 & & & - & - & - & _ & _ & _ & + & _ & - & - & - & + & \\
\hline
\end{tabular}


facies of the Žatec Delta). This similarity may partly be due to the presence of facies that are common to both members. In the coal facies, the most common plants are Salvinia reussii among pteridophytes, Glyptostrobus, Taxodium and Quasisequoia among conifers, and Alnus julianiformis, Nyssa bilinica, Laurophyllum saxonicum, Quercus rhenana, Acer tricuspidatum, Craigia bronnii, and Cercidiphyllum among angiosperms (Břeštany Clay, J. Šverma mine). In the delta facies, some more mesophytic elements are abundant, i.e., Daphnogene polymorpha, Podocarpium, Liquidambar, Parrotia, Salix haidingeri, Carya cf. serrifolia, Populus populina, Ulmus pyramidalis, Zelkova, Rosa, "Sapindus", Acer angustilobum, Acer psedomonspessulanum (= Acer integrilobum sensu Walther 1972), and Fraxinus bilinica. The index fossil Schenkiella is also common to the uppermost part of the Bílina Delta (Holešice Member) and the base of the Libkovice Member in the Bílina area. The distinguishing elements are primarily the various species of Pinus, namely those based on cones: Pinus engelhardtii (former P. oviformis sensu Menzel 1901 from the Trmice, Věštany, Břeštany, Most and Chomutov periphery, Stranná), P. urani (P. laricio sensu Menzel 1901 from the Jezeří, Břeštany), and $P$. ornata (Břeštany). A typical combination of angiosperms known in most localities consists of Comptonia, Myrica lignitum, and Trigonobalanopsis (e.g., Nechvalice, Český Újezd, Břeštany, Merkur-North mine). Fagus saxonica re-appears in addition only in the Žatec Delta (Přívlaky, Stranná). Locally, some mostly thermophilous elements appear for the first time, i.e., leaves of Vaccinioides lusatica, Gordonia hradekensis, Symplocos volkeri, and fruits/seeds of Mastixia lusatica, Symplocos sp., and Schisandra moravica (micaceous facies at Jezeří and Kundratice).

The area of the micaceous facies yielded the richest carpological record of the Most Basin (KU 114, KU 115, KU 108, KU 116, KU 127, PVJK 234, Lb 188, P 542), including Acer sp., Azola aff. nana, Azola aff. rossica, Azola aff. ventricosa, cf. Carex sp., cf. Mastixia lusatica, Cladiocarya sp., Cladium trilobatum, Comptonia goniocarpa, Comptonia longistyla, Dulichium sp., Engelhardia macroptera, Eurya stigmosa, Glyptostrobus europaeus, Meliosma wetteraviensis, Myrica ceriferiformis, Myrica sp., Myrica suppanii vel Myrica ceriferiformis, Pinus engelhardtii, Pinus urani, Potamogetom cf. wiesaensis, Pterocarya cf. limburgensis, Selaginella sp., Schisandra moravica, Sparganium cf. camenzianum, Spirematospermum wetzleri, Stratiotes kaltennordheimensis, Symplocos sp., and Vitaceae gen. et sp. indet.

Higher levels of the Libkovice Member, just below the Lom Seam, are characterised by a diversified flora consisting mostly of palaeosubtropical elements, such as Laurus abchasica, Laurophyllum pseudovillense, Laurophyllum pseudoprinceps, Gordonia hradekensis, along with Quercus kubinyii, Lygodium, and Platanus
Table 2. Summary of the floral composition of the localities studied from the Lom Member (see also Appendix). - Abbreviations: C (cone), Ec (endocarp), F (fruit), L (leaf), S (seed), Sp (spore), 1 - MR 59, 2 Dolní Jiřetín, 3 - OS 9, 4 - LOM 15, 5 - LOM 16.

\begin{tabular}{|c|c|c|c|c|c|c|}
\hline \multirow{2}{*}{ Taxa } & \multirow{2}{*}{ Organs } & \multicolumn{5}{|c|}{ Cores/Localities } \\
\hline & & 1 & 2 & 3 & 4 & 5 \\
\hline cf. Alnus sp. & $\mathrm{L}$ & - & - & - & - & + \\
\hline Azolla aff. nana & $\mathrm{Sp}$ & + & - & - & - & - \\
\hline Azolla aff. rossica & $\mathrm{Sp}$ & + & - & - & - & - \\
\hline Azolla aff. ventricosa & $\mathrm{Sp}$ & + & - & - & - & - \\
\hline Decodon sp. & $\mathrm{L}$ & - & - & + & - & - \\
\hline Glyptostrobus europaeus & $\mathrm{C}, \mathrm{S}, \mathrm{L}$ & - & - & - & - & + \\
\hline Hemitrapa heissigii & $\mathrm{F}$ & - & + & - & - & - \\
\hline Myrica undulatissima & $\mathrm{L}$ & - & - & - & - & + \\
\hline Nyssa gmelinii & $\mathrm{L}$ & - & - & - & - & + \\
\hline Poaceae vel Cyperaceae indet. & $\mathrm{L}$ & - & + & + & - & - \\
\hline Potamogeton cf. wiesaensis & $\mathrm{Ec}$ & + & - & - & - & - \\
\hline Pronephrium stiriacum & $\mathrm{L}$ & - & - & + & - & - \\
\hline Quasisequoia couttsiae & C, S, L & - & - & - & - & + \\
\hline Salix cf. varians & $\mathrm{L}$ & - & - & + & - & - \\
\hline Salvinia reusii & $\mathrm{Sp}, \mathrm{L}$ & + & - & - & + & - \\
\hline
\end{tabular}

neptuni (cores MR 58, MR 59, LiH 13). This type of the flora is limited to the central part of the Most Basin (see Table 1).

\section{Lom Member}

The flora of the Lom Member (Table 2) is so far only fragmentally known. Most of the plant remains come only from the coal facies, and are facies-influenced. Representatives of the aquatic flora are more diversified, as indicated mostly by carpological material (Dolní Jiřetín, cores LOM 15, MR 59) - i.e., Salvinia reusii, Azola aff. nana, Azola aff. rossica, Azola aff. ventricosa, Hemitrapa heissigii, and Potamogeton cf. wiesaensis. A few species have been identified based on leaf compressions (LOM 16, MR 59, Os 9, Dolní Jiřetín), such as Pronephrium stiriacum, Glyptostrobus europaeus, Quasisequoia couttsiae, Myrica undulatissima, Nyssa gmelinii, Decodon sp., cf. Alnus sp., Salix cf. varians, and Poaceae vel Cyperaceae gen. et sp. indet. Uniform accumulations in specific layers (e.g., Salix and Decodon in Os 9) are typical of this coal seam. The mesophytic part of the spectrum is not available from the macrofossil record, so a detailed comparison with adjacent floras cannot be made. It is true that the coal facies includes elements unknown in the Holešice Member (e.g., Myrica undulatissima). Furthermore, the finding of a single fruit of Hemitrapa from the Ležáky mine (Wojcicki \& Kvaček 2002) is equivocal and does not allow identification with the mass occurrence of Hemitrapa heissigii in 
the Lom Member. The Salesius quartzstone has so far yielded only a few species, including Carya pusilla (Hurník 2001), and cannot contribute much to the floral characteristics of this locality.

\section{Phytostratigraphical correlations}

Plant megafossil assemblages are not the best way of dating. The following consideration may help to correlate the plant assemblages of the Most Basin with others in the Bohemian Massif and its periphery. The system of floral assemblages ("Florenkomplexe") in the sense of Mai (1995) has also been considered. All of these have been based on the macrofossil record.

The flora of the locality Přivlaky shows fossil elements in common with the floras of the Pertipsy area and the "Hlavačov Gravel and Sand" (Teodoridis 2004, 2006). However, based on a study of the drilling documentation and profiles from this area (Anonym 1980), it is possible to confirm the correlation of this locality with the basal part of the Libkovice Member of the Most Formation (Rajchl in Teodoridis 2004, fig. 5). Similarly, the stratigraphical position of the fossil material from the cores from the localities Břeštany, Břežánky (Břeštany Clay), Čermníky, Dolany, Soběsuky, Nechranice, Nechvalice, and from the opencast mines J. Šverma, ČSA and Merkur-North, is also clear (e.g., Jirotka 1976). Stratigraphically, they all belong to the Libkovice Member. According to the composition of the above-mentioned floras, mainly Schenkiella credneri, Vaccinioides lusatica, Engelhardia macropteralE. orsbergensis, Pinus engelhardtii/P. rigios, and Trigonobalanopsis rhamnoides/Trigonobalanopsis exacantha, these levels have been correlated to the Bílina-Brandis floral assemblage sensu Mai \& Walther (1991), i.e., floral zone IV sensu Mai (1967). Additional floral elements occur in cores MR 59, MR 58, LOM 16, and Os 9 that stratigraphically correspond to the deposits closely underlying the Lom Seam within the Libkovice Member (Bůžek et al. 1993). These floras have a subtropical character and are usually correlated with the assemblage of Eichelskopf-Wiesa sensu Mai (1995), or floral zone VI sensu Mai (1967; Ottnangian-Karpatian). Newly discovered elements of this flora include Laurus abchasica, Cedrelospermum sp., Quercus kubinyii, and Laurophyllum pseudovillense. The persisting thermophilous elements, e.g. Lygodium, Platanus neptuni, emphasize warming trends. The floras of the Libkovice Member can be correlated with those of the Upper Coal Seam of the Hrádek Basin (Holý 1974, 1975a, b, 1976, Teodoridis 2003b) based on the occurrence of a unique endocarp fragment of cf. Masixia lusatica Mai from core PVJK 234 (depth 70-71 m). We must revise the original assumption of Teodoridis (2003b, p. 30), who correlated all floras of the Lower, Middle, and Upper Coal Seam in the Hrádek part of the Zittau Basin with the floral assemblage of Eichelskopf-Wiesa sensu Mai (1995) on the basis of similarities. The new record of Mastixia corroborates the phytostratigraphical correlation of the floras from the Libkovice Member with the Upper Coal Seam of the Hrádek part of the Zittau Basin.

The flora of the Lom coal seam (Lom Member) is too poor to be reliably utilised for phytostratigraphy. Based on its superposition, this level can be correlated with the same floral assemblages mentioned above. Still, the appearance of younger elements like Hemitrapa heissigii and Nyssa cf. haidingeri (= Nyssa gmelinii) suggests links with the oldest floras of the Younger Bavarian Freshwater Molasse (MN 4b zone) and Wackersdorf in Germany (Knobloch \& Kvaček 1976, Wojcicki \& Kvaček 2002b, Böhme, personal communication).

\section{Vegetation of the Libkovice Member, and palaeoenvironmental signals}

It is possible to distinguish several partial associations that are defined by specific ecological factors and mutually integrated on their ecotons. In the Břeštany and Krušné hory Mts. and Ervěnice areas, an atypical coniferous peat-forming swamp forest is identical to the association of Glyptostrobus sensu Kvaček \& Bůžek (1982) characteristically developed for the main coal seam of the Holešice Member. The dominant elements are representatives of the family Taxodiaceae, i.e., Glyptostrobus europaeus (E4) and Quasisequoia couttsiae (E4), which are well represented also in the following association. There is also a mixed swamp forest overlapping with the coniferous swamp forest towards the shore. This is comparable to the NyssaTaxodium association sensu Kvaček \& Bůžek (1982), and is typically developed in the Most-Bílina paleofloristic area sensu Hurník (1961), and also in the Libkovice Member, mainly in the Břeštany area, and rarely elsewhere (Šverma mine, Čermníky). Besides the above mentioned elements of Taxodiaceae, this association also includes $T a$ xodium dubium (E4), Quercus rhenana (E3), Alnus julianiformis (E3), Ulmus pyramidalis (E3), Acer tricuspidatum (E3), Craigia bronnii (E3), Dombeyopsis lobata (E3), Cercidiphyllum crenatum (E3), Fraxinus bilinica (E3), Nyssa bilinica (E3-2), Salix varians (E2), Myrica (E2), and Woodwardia muensteriana (E1). The riparian forest is mainly confined to sandy clay or sand of the Žatec Delta (Přívlaky). The composition of this riparian forest corresponds to the Parrotia - Ulmus pyramidalis association sensu Kvaček \& Bůžek (1982), or the association of the levée riparian mixed deciduous broad-leaved forest sensu Boulter et al. (1993). It includes Fagus saxonica (E3), Carya cf. 
serrifolia (E4), Zelkova zelkovifolia (E4), Ulmus pyramidalis (E3), Liquidambar europaea (E3), Alnus sp. sensu Bůžek (E3), "Parrotia" pristina (E2), Salix haidingeri (E2), Rosa europaea (E2), Comptonia difformis (E2), Acer angustilobum (E3-2), Daphnogene polymorpha (E3), and Podocarpium podocarpum (E2). Free-floating aquatic vegetation corresponds to the association of Salvinia reussii sensu Kvaček \& Bůžek (1982, p. 20). It includes Salvinia reussii (E1), Azolla sp. (E1), Stratiotes (E1), and Potamogeton $\mathrm{sp}$. (E1). The aquatic vegetation often overlaps distally with the coniferous swamp forest, mixed swamp forest, and the association of canebrakes. This association is comparable to the Decodon - Poaceae vel Cyperaceae association sensu Kvaček \& Bůžek (1982), or to horizons of aquatic vegetation sensu Hurník (1961, 1973), and is typical of aquatic rooted elements that bordered riparian or mixed swamp forests. The association of canebrakes includes Decodon, Poaceae vel Cyperaceae (E1), and Sparganium sp. (E1).

The most typical forest vegetation associated with the sandy and micaceous facies is the evergreen broad-leaved forest mixed with pine stands. This association occupied crystalline rock elevations of the Krušné hory Mts. where mesophytic and acid biotopes covered by homogenous Pinus stands (E3) combined with Lauraceae (Laurophyllum, Daphnogene - E3-2), Theaceae (Eurya - E3-2), Comptonia (E2), Myrica (E2), Symplocos (E3-2), Toddalia (E2), Mastixia (E3-2), and as accessory elements Leguminosites (E3-2), Laurus abchasica (E3), Gordonia hradekensis (E3-2), Quercus kubinyii (E3), Lygodium (E1), Cedrelospermum (E2), and Platanus neptuni (E4). This assemblage of typical elements occurs in the lacustrine sediments beneath the Lom Seam, and overlaps towards to the centre of the basin with the swamp and riparian forests of Glyptostrobus (E4), Quasisequoia (E4), Alnus julianiformis (E3), Acer tricuspidatum (E3), and Myrica $(\mathrm{E} 2)$.

In terms of the system proposed by Kvaček \& Bůžek (1982), it corresponds to the associations of Comptonia-Pinus oviformis, Pinus-Laurophyllum pseudoprinceps, and Quercus kubinyii-Myrica lignitum, or to the coline forest sensu Boulter et al. (1993).

\section{Vegetation of the Lom Member}

The macrofossils obtained so far from the Lom Seam reflect a coal-forming swamp forest of Glyptostrobus (E3), Myrica (E2-3), Salix (E2-3), Nyssa (E2-3), and Pronephrium (E1) with a high groundwater table. Open water between the trees allowed the spreading of both freefloating (Azolla, Hemitrapa) and rooted (Decodon, Cyperaceae vel Poaceae) aquatic vegetation.

\section{Paleaoclimatic signals based on the CLAMP analysis}

The CLAMP (Climate-Leaf Analysis Multivariate Program) software has been developed for palaeoclimatic estimates based on arboreal dicotyledonous leaf assemblages (Wolfe 1993). The advantage of this method is its physiognomic approach, which does not require determinations of leaf fossils into the natural system. Therefore, it was mostly employed for Late Cretaceous and Early Tertiary localities. Only recently attempts have been made to evaluate younger Tertiary floras with known systematic compositions. Our present attempt is a study of this kind conducted at the localities Přivlaky and Břeštany of the Libkovice Member. The localities have been climatically defined as follows: Břeštany - MAT $=16.5{ }^{\circ} \mathrm{C}, \mathrm{CMMT}=5.7{ }^{\circ} \mathrm{C}$, $\mathrm{WMMT}=27.2^{\circ} \mathrm{C}, 3 \mathrm{WET}=81.9 \mathrm{~mm}, 3 \mathrm{DRY}=49.4 \mathrm{~mm}$; Přívlaky: $\mathrm{MAT}=8.9{ }^{\circ} \mathrm{C}, \mathrm{WMMT}=20.2{ }^{\circ} \mathrm{C}, \mathrm{CMMT}=$ $-1.6^{\circ} \mathrm{C}, 3 \mathrm{WET}=50.6 \mathrm{~mm}$ and $3 \mathrm{DRY}=30.4 \mathrm{~mm}$ (based on 174 comparable sites of recent vegetation) - see Table 3 .

Table 3. Results of the CLAMP analysis from the flora of Přivlaky and floras of the Břeštany Clay. - Symbols: MAT (Mean Annual Temperature), WMMT (Warmest Month Mean Temperature), CMMT (Coldest Month Mean Temperature), 3WET (Precipitation during 3 Consecutive Wettest Months), 3DRY (Precipitation during 3 Consecutive Driest Months) and SD (Standard Deviation).

\begin{tabular}{lccc}
\hline $\begin{array}{l}\text { Localities } \\
\text { Climate parameters }\end{array}$ & Přívlaky & Břeštany & SD \\
\hline MAT $\left({ }^{\circ} \mathrm{C}\right)$ & 8.9 & 16.5 & 1.7 \\
WMMT $\left({ }^{\circ} \mathrm{C}\right)$ & 20.2 & 27.2 & 1.8 \\
CMMT $\left({ }^{\circ} \mathrm{C}\right)$ & -1.6 & 5.7 & 2.5 \\
3WET $(\mathrm{mm})$ & 50.6 & 81.9 & 13.8 \\
3DRY $(\mathrm{mm})$ & 30.4 & 49.4 & 9.0 \\
\hline
\end{tabular}

The large difference in climatic estimates between both localities is probably due to different environmental conditions. The Přívlaky assemblage represents a riparian, mostly deciduous forest, while the Břeštany assemblage is a mixture of upland and swamp forests. The results of this analytical research (except the mentioned anomaly) are generally similar to climate estimates for the floras of the Břeštany Clay as published by Mai \& Walther (1983, 1991), Kvaček (1998), and Teodoridis (2004, 2006), particularly in respect of the floral composition. The climate regime of these localities was optimally humid and warm-temperate (i.e., MAT $=10-15{ }^{\circ} \mathrm{C}, \mathrm{CMMT}=0{ }^{\circ} \mathrm{C}$, $\mathrm{WMMT}=24-26{ }^{\circ} \mathrm{C}$ and MAP $=1800 \mathrm{~mm}$ ). The reconstructed vegetation corresponds to the warmer parts of the Mixed Mesophytic Forest of Southeast Asia, which was climatically defined by Wolfe (1979) as follows: MAT = $10-13{ }^{\circ} \mathrm{C}, \mathrm{CMMT}=1-(-2){ }^{\circ} \mathrm{C}$ and MART $=20-29{ }^{\circ} \mathrm{C}$. Higher levels of the Libkovice Member have been correlated with the global curve of MAT on the basis of the variations 
in the stomatal index of Laurophyllum pseudoprinceps and Laurus abchasica (Kuerschner \& Kvaček submitted). An increase in MAT of about $3{ }^{\circ} \mathrm{C}$ was given for the level below the Lom coal seam. Thus, the MAT for this level is estimated as $19 \pm 1{ }^{\circ} \mathrm{C}$. This value agrees well with the changing vegetation from the Mixed Mesophytic Forest at the base of the Libkovice Member to the Subtropical Nothophyllous Evegreen Forest in its higher levels. The climatic data derived from the living East Asian vegetation for the Nothophyllous Evergreen Forest, according to Wolfe (1979), are: $\mathrm{MAT}=13-20^{\circ} \mathrm{C}, \mathrm{CMMT}=>1{ }^{\circ} \mathrm{C}$, MART $=$ 25-26.5 ${ }^{\circ} \mathrm{C}$.

The CLAMP method has been most frequently applied to plant assemblages of Late Cretaceous to early Tertiary floras, where controls based on the nearest-living relative method have failed. The application of CLAMP to the later Tertiary (e.g., Kvaček \& Walther 2004, Teodoridis 2004) has shown that relevant climatic estimates can also be obtained for more recent plant assemblages. According to our experience, and to previous analyses of ancient vegetation (Kovar-Eder et al. submitted), the zonal assemblages, i.e., those outside swampy and flooded riparian settings, are more reliable climatic signals. The "wet soil effect" biases climatic estimates derived from leaf physiognomy. This fact has been reported several times by previous authors (Burnham et al. 2001, Kowalski \& Dilcher 2003). We must emphasize that this phenomenon has not been taken into account in current CLAMP studies. We therefore warn other researchers not to rely on purely azonal (intrazonal) plant assemblages as the sole source for studies using CLAMP. Another difficulty with which we were confronted in working with CLAMP was the inaccuracy of evaluating the fossil floral spectrum based on leaf impressions (mostly determined as morphotypes). However, extant models of vegetation are based on the natural species (i.e., variation in foliar morphology is included), and can be evaluated without any error in the CLAMP databases. In the case of the Břeštany assemblage in particular, the foliage types (morphotypes) have been partly delimited intuitively when experience from previous cuticular studies have not been available. The question is how far a natural variation of a single morphotype can go. In legumes and lauroids the differentiation of morphotypes with natural extent is usually problematic without epidermal characteristics. Considering the above weak points of the CLAMP analysis, the results cannot be accepted absolutely, but can show only the approximate climatic characteristics of an environment. In our opinion, the CLAMP method can complement others that suffer from different weaknesses (e.g., Mossbrugger \& Utescher 1997), particularly in neglecting evolutionary change in the autecology of extant descendants (Kvaček submitted). The CLAMP method, as in other methods based on leaf physiognomy (for details see Royer et al. 2005), crucial weakness that are possible sources of error, are derived from the uncertain delimitation of morphotypes, particularly in impression floras.

\section{Acknowledgments}

We appreciate useful discussions on the geology of the Most Basin with M. Rajchl, K. Mach, Z. Dvořák, M. Malkovský, A. Elznic, and the late S. Hurník. Most of the material studied was collected by the late Č. Bůžek, F. Holý, and the second author. Comparative palaeobotanical data and specimens from Germany were kindly supplied by H. Walther and L. Kunzmann, Dresden. We acknowledge help extended by the curators of the collections, particularly J. Kvaček of the National Museum in Prague, B. Meller in Vienna, E. Marttineto in Torino, and O. Janeček in Tušimice. Preliminary results on fluctuations of the $\mathrm{CO}_{2}$ concentrations in the Most Basin have been obtained through collaboration with W. Kuerschner, Utrecht. Our thanks also go to R.A. Spicer at Milton Keynes for consultation concerning CLAMP, and to A. G. Corres for the linguistic revision of the manuscript. The reviewers M.C. Boulter, London and J. Sakala, Prague suggested useful improvements to the manuscript. The study was supported by the grants: GAUK (Grant Agency of Charles University) No. 3239/2004 and GAČR (Grant Agency of the Czech Republic) Nos 205/04/0099 and 105/06/0653.

\section{References}

ANONYM 1980. Atlas geologických řezů severočeské hnědouhelné pánve. Báňské stavby, Osek a SHD Most, Most.

Boulter, M.C., Hubbard, R.N.L.B. \& KvaČEK, Z. 1993. A comparison of intuitive and objective interpretations of Miocene plant assemblages from north Bohemia. Palaeogeography, Palaeoclimatology, Palaeoecology 101, 81-96.

Bucha, V., Elznic, A., HoráČeK, J., MalkovskÝ, M. \& PAZDERKOVÁ, A. 1987. Paleomagnetic timing of the Tertiary of the North Bohemian Brown-Coal Basin. Věstník Ústředního ústavu geologického 62(2), 83-95.

BuRnham, R.J., Pitman, N.C.A., Johnson, K.R. \& WiLF, P. 2001. Habitat-related error in estimating temperatures from leaf margin in a humid tropical forest. American Journal of Botany 3, 24-29.

BƯŽEK, Č. 1963. Dosavadní výsledky paleobotanického výzkumu $v$ třetihorách severozápadních $\breve{C} e c h$. Unpublished report.

BỦŽEK, Č. 1971. Tertiary flora from the northern part of the Pětipsy area (North-Bohemian Basin). Rozpravy Ústředního ústavu geologického 36, 1-118.

BưŽEK, Č. 1984. Návrh na ochranu lokality Hradiště u Černovic na Chomutovsku. Památky-Přiroda-Život 16(2), 49-54.

BưŽEK, Č. \& HolÝ, F. 1964. Small-sized plant remains from the Coal Formation of the Chomutov-Most-Teplice Basin. Sborník geologických věd, Paleontologie 4, 105-138.

BƯŽEK, Č., KvaČEK, Z., DvořÁK, Z. \& Prokš, M. 1993. Terciérní vegetace severočeské hnědouhelné pánve v pohledu nových dokladů. Zpravodaj SHD 11, 38-51.

DoMÁCí, L. 1977. Litostratigrafie třetihorních sedimentů v hnědouhelné severočeské pánvi. Acta Universitatis Carolinae, Geologica 1975(1), 75-80. 
DVOŘÁK, Z. \& MACH, K. 1999. Deltaic deposits in the North-Bohemian brown coal basin and their documentation in the Bílina opencast mine. Acta Universitatis Carolinae, Geologica 43(4), 633-641.

ElzNIC, A. 1964. Severozápadní omezení chomutovsko-mostecko-teplické pánve. Věstník Ústředního ústavu geologického $38(4), 245-253$.

ElzNIC, A. 1973. Sedimenty neogénu a vývoj uhelné sloje v mostecké části severočeské pánve. Věstník Ústředního ústavu geologického 24, 175-204.

Elznic, A., FišERA, E., Hurník, S., MalkovskÝ, M. \& VÁCl, J. 1986. Návrh neformálního stratigrafického členění terciéru severočeské hnědouhelné pánve. Unpublished report, Geofond, Praha.

Elznic, A., ČADKovÁ, Z. \& DuŠEK, P. 1998. Paleogeografie terciérních sedimentů severočeské pánve. Sborník geologických věd, Geologie 48, 19-46.

ENGElHARDT, H. 1877. Über die fossilen Pflanzen des Süsswassersandstein von Tschernowitz. Nova Acta Leopoldina 39, 359-394.

EtTingshausen, C. vON 1866. Die fossile Flora des Tertiärbeckens von Bilin I. Denkschriften der kaiserlichen Akademie der Wissenschaften, Mathematisch-naturwissenschaftliche Klasse 28, 1-98.

Ettingshausen, C. von 1868. Die fossile Flora des Tertiärbeckens von Bilin II. Denkschriften der kaiserlichen Akademie der Wissenschaften, Mathematisch-naturwissenschaftliche Klasse 28, 191-242.

ETtingShaUSEN, C. vON 1869. Die fossile Flora des Tertiärbeckens von Bilin III. Denkschriften der kaiserlichen Akademie der Wissenschaften, Mathematisch-naturwissenschaftiche Klasse 29, 1-110.

FEJFAR, O. 1989. The Neogene vertebrate paleontology sites of Czechoslovakia: A contribution to the Neogene terrestric biostratigraphy of Europe based on rodents, 211-236. In LiNDSAY, E.H., FAhlbusch, V. \& MeIn, P. (eds) Proceedings of a NATO Advanced Research workshop on European Neogene mammal chronology. Plenum Press, New York.

FEJFAR, O. \& KVAČEK, Z. 1993. Exkursionsführer zur Exkursion "Tertiary basins in Northwest Bohemia", 63. Jahrestagung der Paläontologischen Gesellschaft. 35 pp. Charles University, Prague.

HiCKEY, L.J. 1973. Classification of the architecture of dicotyledonous leaves. American Journal of Botany 60(1), 17-33.

Holý, F. 1974. Neogénní mastixioidní květena svrchního slojového pásma z lomu Kristina (Hrádek $n$. N.). Ph.D. thesis, National Museum, Prague.

HoLÝ, F. 1975a. Representatives of the family Mastixiaceae Calestani 1905 in the Bohemian Tertiary. Acta Musei nationalis Pragae, Series B - historia naturalis 31(3-5), 123-147.

HolÝ, F. 1975b. On some new species from the Mastixiaceae-flora taphocenose from the Miocene near Hrádek nad Nisou (Zittau Basin, North Bohemia). Acta Musei nationalis Pragae, Series B - historia naturalis 31(3-5), 109-122.

HoLY, F. 1976. The assemblage of autochthonous coal plant-remains from the Miocene near Hrádek nad Nisou (Zittau Basin, North Bohemia). Acta Musei nationalis Pragae, Series B historia naturalis 32(1), 1-13.

HuRNík, S. 1959. Zpráva o paleontologickém výzkumu cho- mutovsko-mostecko-teplické pánve. Zprávy o geologických výzkumech $v$ roce 1957, 78-80.

HURNík, S. 1960. Př́íspěvek k tektonickým poměrům střední části jižního okraje chomutovsko-mostecko-teplické pánve. Věstník Ústředního ústavu geologického 34(4), 337-340.

HuRNí, S. 1961. Paleofloristické oblasti nadložní série v severočeském terciéru a jejich vztah $\mathrm{k}$ lithofaciálnímu vývoji. $\breve{C}$ asopis pro mineralogii a geologii 4, 419-428.

HuRNík, S. 1973. Vegetation cover of the onshore part of the Miocene delta near Most in the North Bohemian brown-coal basin. Časopis pro mineralogii a geologii 18(1), 57-62.

HuRNík, S. 2001. Zavátá minulost Mostecka. Sborník Okresního muzea $v$ Mostě, Řada prírodní 23, 1-139.

JiROTKA, P. 1976. Dílči zpráva. Hydrogeologické zpracování vrtů PVJK-202/KU 113, PVJK-203/KU 114, HVJK-204/KU 115. Unpublished report.

KNOBLOCH, E. \& KvaČEK, Z. 1976. Miozäne Blätterfloren vom Westrand der Böhmischen Masse. Rozpravy Ústředního ústavu geologického 42, 1-131.

KonZALOvÁ, M. 1976. Micropalaebotanical (palynological) research of the Lower Miocene of Northern Bohemia. Rozpravy ČSAV, Řada matematických a prírodních věd 86(12), 1-75.

Kovar-Eder, J., JechoreK, H., KvaČeK, Z. \& PARAshiv, V. Submitted. The integrated plant record to reconstruct Neogene zonal vegetation in Europe. Palaios.

Kowalski, E.A. \& DilcheR, D.L. 2003. Warmer paleotemperatures for terrestrial ecosystems. Proceedings of the National Academy of Sciences, USA 100, 167-170.

KuERSCHNER, W. \& KVAČEK, Z. Submitted. C4 plant and climate evplution linked to Miocene $\mathrm{CO}_{2}$. Abstracts. $7^{\text {th }}$ European Palaeobotany - Palynology Conference, 6-11, Sept. 2006, Prague.

KVAČEK, Z. 1985. Kutikulární analýza neogénních dřevin střední Evropy. DrSc. thesis, Institute of Geology and Geotechnics, CSAV, Prague.

KVAČEK, Z. 1998. Bílina: a window on Early Miocene marshland environments. Review of Palaeobotany and Palynology 101, 111-123.

KvAČEK, Z. 2005. Early Miocene records of Craigia (Malvaceae s.1.) in the Most Basin, North Bohemia - whole plant approach. Journal of the Czech Geological Society 49, 161-171.

KVAČEK, Z. Submitted. The extant nearest relatives of thermophile European Tertiary elements reliably reflect climatic signal? In Bruch, A.A., Uhl, D. \& MosbrugGer, V. (eds) Miocene climate in Europe - patterns and evolution. Palaeogeography, Palaeoclimatology, Palaeoecology.

KVAČEK, Z. \& BƯŽEK, Č. 1982. Třetihorni společenstva severočeské hnědouhelné pánve ve vztahu k litofaciálnímu vývoji. Unpublished report, Ústav geologie a geotechniky ČSAV, Praha.

KvaČeK, Z., BöHME, M., DvořáK, Z., KonZalovÁ, M., MaCh, K., Prokop, J. \& RAJChL, M. 2004. Early Miocene freshwater and swamp ecosystems of the Most Basin (north Bohemia) with particular reference to the Bílina Mine section. Journal of the Czech Geological Society 49, 1-40.

KvaČEK, Z. \& HuRNí, S. 2000. Revision of Miocene plants preserved in baked rocks in the North Bohemian Tertiary. Acta Musei nationalis Pragae, Series B - historia naturalis 56(1-2), 1-48. 
KvaČEK, Z. \& WALther, H. 2004. Oligocene flora of Bechlejovice at Děčín from the neovolcanic area of the České Středohoří Mountains, Czech Republic. Acta Musei nationalis Pragae, Series B - historia naturalis 60, 9-60.

Lotsch, D., Ahrens, H., Kretzschmar, W., Walther, H., FisCHER, O. \& HEINICKE, L. 1994. Gliederungsmöglichkeiten der Thierbacher Schichten nach Ergebnissen paläobotanischer Untersuchungen. Hallesches Jahrbuch der Geowissenschaften 16, 1-21.

MACH, K. 1997. A logging correlation scheme for the main coal seam of the North Bohemian brown coal basin, and the implications for the palaeogeographical development of the basin. In GAYAER, R. \& PEŠEK, J. (eds) European coal geology and technology, Geological Society Special Publication 125, 309-320.

MACH, K. 2002. Anomální stavba hlavní hnědouhelné sloje v prostoru miocénní bílinské délty a jejich geneze. $\mathrm{Ph} . \mathrm{D}$. thesis, Charles Univesity, Prague.

MAI, D.H. 1967. Die Florenzonen, der Florenwechsel und die Vorstellung über den Klimaablauf im Jungtertiär der Deutschen Demokratischen Republik. Abhandlungen des zentralen geologischen Institut 10, 55-82.

MAI, D.H. 1995. Tertiäre Vegetationsgeschichte Europas. Gustav Fischer Verlag, Jena.

MAI, D.H. \& Walther, H. 1983. Die fossilen Floren des Weisselster-Beckens und seiner Randgebiete. Hallesches Jahrbuch der Geowissenschaften 8, 59-74.

MaI, D.H. \& Walther, H. 1991. Die oligozänen und untermiozänen Floren NW - Sachsens und des Bitterfelder Raumes. Abhandlungen des Staatlichen Museums für Mineralogie und Geologie zu Dresden 38, 1-230.

MALKOVSKÝ, M. 1987. Problémy stratigrafie kontinentálního terciéru Českého masívu a severočeské hnědouhelné pánve, 62-64. In BRus, Z. et al. (eds) Geologie oblasti - XXVI. celostátní konference ČSMG, 1987, Most.

MALKOVSKÝ, M. 1995. Některé problémy chronostratigrafického členění terciéru Českého masívu, 25-37. In HAMRŠMíD, B. (ed.) Nové výsledky v terciéru západnich Karpat. Sborník referátů z 11. konference o mladším terciéru, Brno, 25.-26. 4. 1995, Hodonín.

Malkovský, M., Brunerová, Z., BŮŽeK, Č., ČAdeK, J., Čadková, Z., Čech, F., Čuta, J., Domácí, L., Elznic, A., Fejfar, O., Gabriel, M., Gabrielová, N., Hercogová, J., Hokr, Z., KaČURa, G., KodyMOVÁ, A., KopeckÝ, L., Králík, F., Kurendová, J., Líbalová, J., Malecha, A., Manová, M., Mašín, J., PlzáK, V., RÁKosovÁ, M., Řeháková, Z., SchováneK, P., Schovánková, D., Šalanský, K., ŠEbesta, J., S̆MejKal, V., Šrámek, J., S̆TEMPROK, M., TÁSLER, R., TYRÁČEK, J. \& URBAN, J. 1985. Geologie severočeské hnědouhelné pánve a jejího okolí. Ústřední ústav geologický, Praha.

Menzel, P. 1901. Die Gymnospermen der nordböhmischen Braunkohlenformation I. Abhandlungen der naturwisschaftlichen Gesellschaft Isis in Dresden 1900(2), 49-69.

Moravec, J., Jeník, J., Kolbek, J., Krahulec, F., Husová, M., KvĚT, J., RybníČEK, K., RybníčKovÁ, E., NEUHÄUSLOVÁ-Novotná, Z., Neuhäusl, R., BlažKová, D., KREČMer, V., KropáČ, Z., SAMEK, V. \& ŠTĚPÁn, J. 2000. Fytocenologie. Academia, Praha.
Mosbrugger, V. \& Utescher, T. 1997. The coexistence approach - a method for quantitative reconstructions of Tertiary terrestrial palaeoclimatic data using plant fossils. Palaeogeography, Palaeoclimatology, Palaeoecology 134, 61-86.

ProchÁZKA, M. 1954. Paleontologický výzkum chomutovské a pětipeské pánve. Zprávy o geologických výzkumech v roce 1953, 166-174.

RAJCHL, M. \& UliČNÝ, D. 2005. Depositional record of an avulsive fluvial system controlled by peat compaction (Neogene, Most Basin, Czech Republic). Sedimentology 52, 601-625.

Royer, D.L., Wilf, P., JANESKo, D.A., Kowalski, E.A. \& DiLCHER, D.L. 2005. Correlating climate and plant ecology with leaf size and shape: potential proxies for the fossil record. American Journal of Botany 92, 1141-1151.

SuHR, P. 2003. The Bohemian Massif as catchment area for the NW European Tertiary Basin. GeoLines 15, 147-159.

TeOdoRIDIs, V. 2002. Tertiary flora and vegetation of the Hlavačov gravel and sand and the surroundings of Holedeč in the Most Basin (Czech Republic). Acta Musei nationalis Pragae, Series B - historia naturalis 57(3-4), 103-140.

TEODORIDIS, V. 2003a. Flóry a vegetace terciérnich fluviatilních sedimentů středočeské a severočeské oblasti a jejich ekvivalenty v mostecké pánvi. Ph.D. thesis, Charles Univesity, Prague.

TEODORIDIs, V. 2003b. Early Miocene carpological material from the Czech part of the Zittau Basin. Acta Palaeobotanica 43(1), 9-49.

TEODORIDIs, V. 2004. Floras and vegetation of Tertiary fluvial sediments of Central and Northern Bohemia and their equivalents in deposits of the Most Basin (Czech Republic). Acta Musei nationalis Pragae, Series B - historia naturalis 60(3-4), 113-142.

TEODORIDIS, V. 2006. Tertiary flora and vegetation of the locality Př́vlaky near Žatec (Most Basin). Acta Universitatis Carolinae, Geologica, 2003, 47, 165-177.

UliČNÝ, D., RAJChl, M., MACH, K. \& DvoŘÁK, Z. 2000. Sedimentation and synsedimentary deformation in rift-margin, Lacustrine Delta System: the Bílina Delta (Miocene), Most Basin. GeoLines 10, 84-95.

UnGER, F. 1841-1847. Chloris protogaea. Beiträge zur Flora der Vorwelt, 1-10. W. Engelmann, Leipzig.

UnGER, F. 1852. Iconographia plantarum fossilium. Denkschriften der kaiserlichen Akademie der Wissenschaften, Mathematisch-naturwissenschaftliche Klasse 4, 73-118.

UnGer, F. 1861. Sylloge plantarum fossilium I. Denkschr. Denkschriften der kaiserlichen Akademie der Wissenschaften, Mathematisch-naturwissenschaftliche Klasse 19, 1-48.

UnGeR, F. 1864. Sylloge plantarum fossilium II. Denkschriften der kaiserlichen Akademie der Wissenschaften, Mathematisch-naturwissenschaftliche Klasse 22, 1-36.

UnGeR, F. 1866. Sylloge plantarum fossilium III. Denkschriften der kaiserlichen Akademie der Wissenschaften, Mathematisch-naturwissenschaftliche Klasse 25, 1-76.

VÁcL, J. \& MALKovsKÝ, M. 1962. Geologie Žatecka (Geologie des Saatzer Gebietes). Sborník Ústředního ústavu geologického, Oddíl geologický 27, 291-330.

VÁNĚ, M. 1961. Př́ispěvek k litostratigrafické pozici salesijských křemenců v severočeské hnědouhelné pánvi. Časopis pro mineralogii a geologii 6(3), 346-355. 
VÁNĚ, M. 1985. Geologické poměry neogénních hlavačovských štěrkopísků mezi Rakovníkem a Holedečí. Sborník Severočeského muzea, Př́rodní vědy 14, 205-218.

VÁNĔ, M. 1999. Geologie Lounska pro třetí tisíciletí. Privately published, Chomutov.

WALtHER, H. 1972. Studien über tertiäre Acer Mitteleuropas. Abhandlungen des Staatlichen Museums für Mineralogie und Geologie zu Dresden 19, 1-309.

WóJCICKI, J.J. \& KVAČEK, Z. 2002a. Schenkiella genus novum, thorny disseminules of unknown affinities from the Lower Miocene of Central Europe. Acta Palaeobotanica 42(2), 109-116.

WósCICKI, J.J. \& KVAČEK, Z. 2002b. Hemitrapa fruits (Trapaceae) in the late Early Miocene Lom Seam, Most Formation, North Bohemia. Acta Palaeobotanica 42(2), 117-124.

\section{Appendix}

List of taxa mentioned in the tables.

Acer angustilobum Heer

Acer pseudomonspessulanum Ung.

Acer sp.

Acer tricuspidatum Bronn sensu Procházka \& Bủžek

Alnus gaudinii (Heer) Knobloch \& Z. Kvaček

Alnus julianiformis (Sternb.) Z. Kvaček \& Holý

Alnus lusatica Mai

Alnus menzelii Ran.-Bobr.

cf. Alnus sp.

Alnus sp. sensu Bůžek

Andromediphyllum sp. n. ("?Rosaceae gen. et sp.")

Azolla aff. nana Dorofeev

Azolla aff. rossica Dorofeev

Azolla aff. ventricosa P. Nikitin sensu Dorofeev

Berchemia multinervis (A. Br.) Heer

Betula sp.

cf. Carex sp.

Carya cf. serrifolia (Goepp.) Kräusel

Cedrelospermum sp.

"Celastrus" pyrrhae Ett.

Cercidiphyllum crenatum (Ung.) R. Brown

Cladiocarya sp.

Cladium trilobatum Mai

Comptonia difformis (Sternb.) Berry

Comptonia goniocarpa Mai

Comptonia longistyla (Nikitin) Dorofeev

Craigia bronnii Z. Kvaček, Bůžek \& Manchester

Daphnogene polymorpha (A. Br.) Ett.

Decodon sp.

Dicotylophyllum sp. n.

cf. Diospyros brachysepala A. Br. sensu Hantke

Diversiphyllum aesculapi (Heer) Bůžek

Dombeyopsis lobata Ung.

Dulichium sp.

Engelhardia macroptera (Brongn.) Ung.

Engelhardia orsbergensis (Weber) Jähnichen, Mai \& Walther

Eurya stigmosa (Ludwig) Mai

Fagus saxonica Z. Kvaček \& Walther
WolfE, J.A. 1979. Temperature parameters of humid to mesic forests of eastern Asia and relation of forests of other regions of the Northern Hemisphere and Australia. U.S. Geological Survey Professional Paper 1106, 1-37.

Wolfe, J.A. 1990. Palaeobotanical evidence for a marked temperature increase following the Cretaceous/Tertiary boundary. Nature 343, 153-156.

Wolfe, J.A. 1993. A method of obtaining climatic parameters from leaf assemblages. U.S. Geological Survey Bulletin 2040, $1-73$.

Wolfe, J.A. \& SPICER, R.A. 1999. Fossil leaf character states: multivariate analysis, 233-239. In JONES, T.P. \& RowE, N.P. (eds) Fossil plants and spores: modern techniques. Geological Society, London.

"Ficus" truncata Heer sensu Bůžek

Fraxinus bilinica (Ung.) Z. Kvaček \& Hurník

Fraxinus macroptera Ett.

Glyptostrobus europaeus (Brongn.) Ung.

Gordonia hradekensis (Z. Kvaček \& Bůžek) Palamarev \& Bozukov

Hamamelidaceae gen. et sp. indet.

Hemitrapa heissigii Gregor

Chaneya oehningensis (Heer) Teodoridis \& Z. Kvaček

Juglans sp.

Laurophyllum nechranicense Bůžek \& Z. Kvaček

Laurophyllum pseudoprinceps Weyland \& Kilpper

Laurophyllum pseudovillense Knobloch \& Z. Kvaček

Laurophyllum saxonicum Litke

Laurophyllum sp. 1

Laurophyllum sp. 2

Laurus abchasica (Kolakovskii \& Shakryl) Ferguson

Leguminosites sp. 1

Leguminosites sp. 2

Liquidambar europaea $\mathrm{A}$. Br.

Lygodium gaudinii Heer

cf. Magnolia sp.

Mahonia bilinica (Ung.) Z. Kvaček \& Bůžek

cf. Mastixia lusatica Mai

Meliosma wetteraviensis (Ludwig) Mai

Myrica ceriferiformis Kownas

Myrica lignitum (Ung.) Sap.

Myrica undulatissima Knobloch \& Z. Kvaček

Myrica sp. 1

Myrica sp. 2

Myrica suppanii Kirchheimer vel M. ceriferiformis Kownas

Nyssa bilinica (Ung.) Z. Kvaček

Nyssa gmelinii (Heer) Mai

Nyssa sp.

Oleinites sp. n.

Paliurus favonii Ung.

Paliurus tiliaefolius (Ung.) Bůžek

"Parrotia" pristina (Ett.) Stur sensu Bůžek

Phyllites sp. 
Pinus engelhardtii Menzel

Pinus ornata (Sternb.) Brongn.

Pinus rigios Ung.

Pinus sp.

Pinus urani (Ung.) Schimper

Platanus neptuni (Ett.) Bůžek, Holý \& Z. Kvaček

Poaceae vel Cyperaceae gen. et. sp. indet.

Podocarpium podocarpum (A. Br.) Herendeen

cf. Populus populina (Brongn.) Knobloch

Populus sp.

Potamogetom cf. wiesaensis Kirchheimer

Pronephrium stiriacum (Ung.) Knobloch \& Z. Kvaček

Pterocarya cf. limburgensis C. \& E.M. Reid

Pungiphyllum cruciatum (A. Br.) Frankenhäuser \& Wilde

Quasisequoia couttsiae (Heer) Kunzmann

Quercus kubinyii (Kováts ex Ett.) Czeczott

Quercus rhenana (Kräusel \& Weyland) Knobloch \& Z. Kvaček

cf. Rhus pyrrhae Ung.

Rosa europaea (Ett.) Z. Kvaček \& Hurník

Sabal major (Ung.) Heer

Salix haidingeri Ett. emend. Bůžek

Salix cf. varians Goepp.

Salvinia reussii Ett.
"Sapindus" falcifolius (A. Br.) A. Br.

Selaginella sp.

Schisandra moravica (Mai) Gregor

Smilax weberi Wessel

Sparganium cf. camenzianum Kirchheimer

Spirematospermum wetzleri (Heer) Chandler

Stratiotes kaltennordheimensis (Zenker) Keilhack

Symplocos sp.

Symplocos volkeri Z. Kvaček

Taxodium dubium (Sternberg) Heer

Tetraclinis salicornioides (Ung.) Z. Kvaček

Thypha latissima A. Br.

Tilia brabenecii Bůžek \& Z. Kvaček

Toddalia maii Gregor

cf. Toxicodendron sp.

Trachelospermophyllum sp.

Trigonobalanopsis exacantha (Mai) Z. Kvaček \& Walther

Trigonobalanopsis rhamnoides (Rossm.) Z. Kvaček \& Walther

Ulmus pyramidalis Goepp.

Vaccinioides lusatica Z. Kvaček \& Walther

Vitaceae gen. et sp. indet.

Vitis stricta (Goepp.) Knobloch

Zelkova zelkovifolia (Ung.) Bůžek \& Kotlaba 